Department of Energy

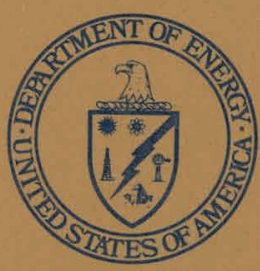

Regional Studies Program

\title{
AN ASSESSMENT OF THE SOLID WASTE IMPACT OF THE NATIONAL ENERGY PLAN
}

February 1978
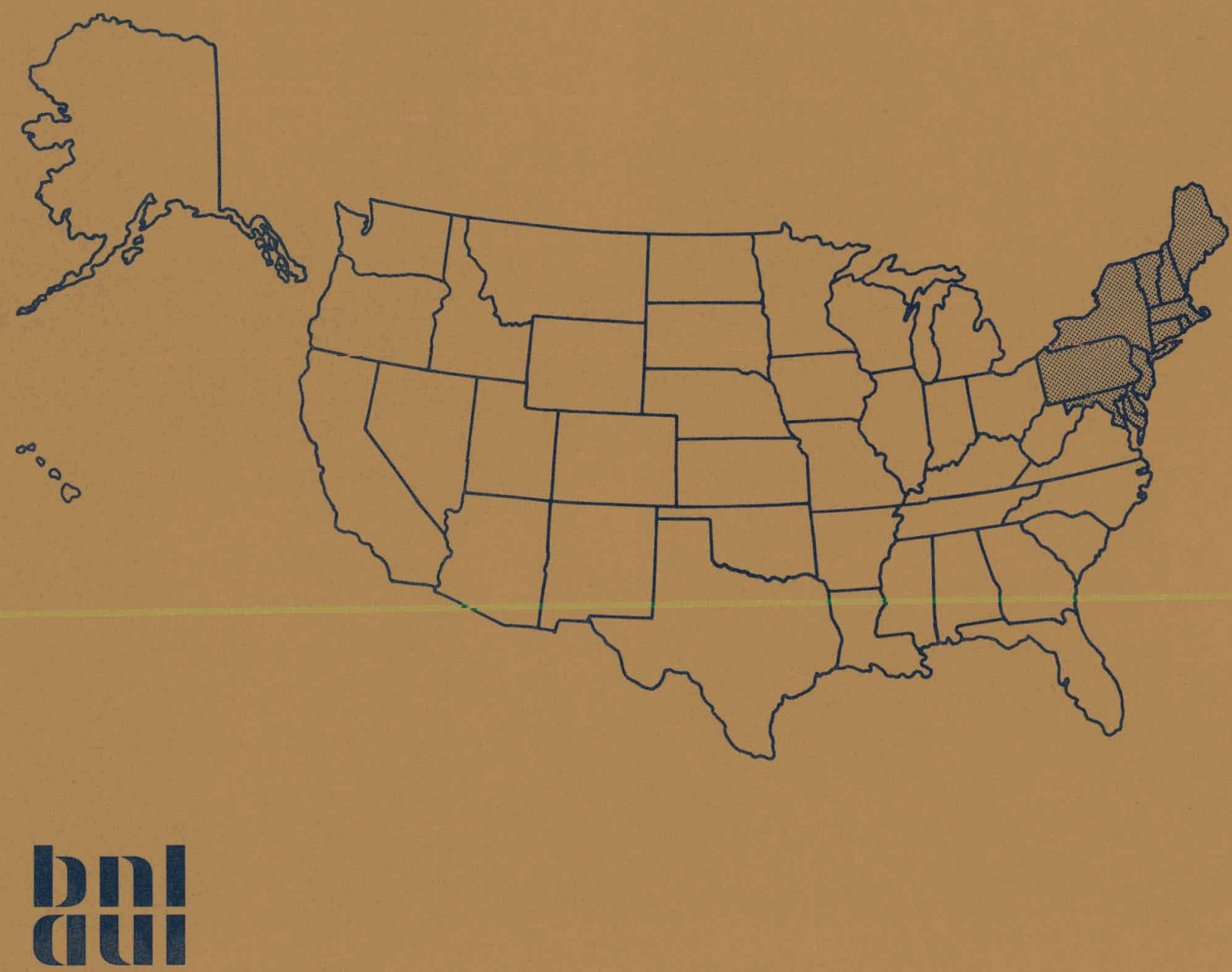

Brookhaven National Laboratory 


\section{DISCLAIMER}

This report was prepared as an account of work sponsored by an agency of the United States Government. Neither the United States Government nor any agency Thereof, nor any of their employees, makes any warranty, express or implied, or assumes any legal liability or responsibility for the accuracy, completeness, or usefulness of any information, apparatus, product, or process disclosed, or represents that its use would not infringe privately owned rights. Reference herein to any specific commercial product, process, or service by trade name, trademark, manufacturer, or otherwise does not necessarily constitute or imply its endorsement, recommendation, or favoring by the United States Government or any agency thereof. The views and opinions of authors expressed herein do not necessarily state or reflect those of the United States Government or any agency thereof. 


\section{DISCLAIMER}

Portions of this document may be illegible in electronic image products. Images are produced from the best available original document. 


\title{
AN ASSESSMENT OF THE SOLID WASTE IMPACT OF THE NATIONAL ENERGY PLAN
}

\author{
P. Meier, E. Rubin, T. Le, R. Stern
}

with contributions by

E. Kaplan, F. Barvenik, and K. Blumer

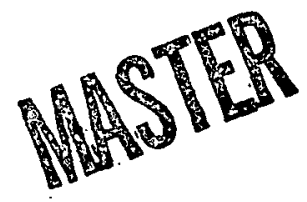

February 1978

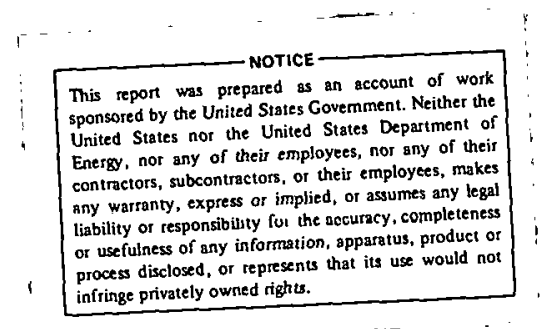

POLICY ANALYSIS DIVISION

NATIONAL CENTER FOR ANALYSIS OF ENERGY SYSTEMS

Brookhaven National Laboratory

Associated Universities, Inc.

Upton, New York 11973

PREPARED UNDER CONTRACT NO. EY-76-C-02-0016 WITH THE UNITED STATES DEPARTMENT OF. ENERGY 


\section{NOTICE}

This report was prepared as an account of work sponsored by the United States Government. Neither the United States nor the I Inited States Dopartmont of Encigy, (DOE), nor any of their employees, nor any of their contractors, subcontractors, or their employees, makes any warranty, express or implied, or assumes any legal liability or responoibility for the accuracy, cumpleteness or usefulness of any intormation, apparatus, product or process disclosed, or represents that iṭ use would not infringe prlvarely owhed rights.

Printed in the United States of America

Available from

National Technical Information Service

U.S. Departmeut of Cumnerce

5285 Port Royal Road

Springfield, VA 22161

Price: Printed Copy $\$ 5.25$; Microfiche $\$ 3.00$

May 1978

790 copies 
This report addresses coal related solid waste management issues arising from the Administration's National Energy Plan (NEP) as proposed early in 1977. Although the legislation that will likely emerge from the Congressional deliberations of late 1977 and early 1978 can be expected to differ quite significantly from the original plan, distribution of this report at the present time appears warranted in light of the general interest in the environmental impact of increased coal utilization, a topic addressed directly by the discussions of this analysis.

It should be noted at the outset, however, that this analysis of NEP impacts assumes full implementation of the Best Available Control Technology (BACT) provisions of the 1977 Clean Air Act Ammendments, with both of the scenarios that form the basis for assessment (a 1985 Base Case, and a 1985 NEP Case) requiring new coal capacity to comply with BACT beyond 1982. The Impact of the BACT requirements themselves on solid waste management problems, which prove to be far greater than those of NEP, are addressed as a separate issue for the Northeastern Region of the Unfted States in another report (BNL 23606, Coal Ut1lization in the Northeast Vol. VIII; Solid Waste Management Issues, February 1978). 
TABLE OF CONTENTS

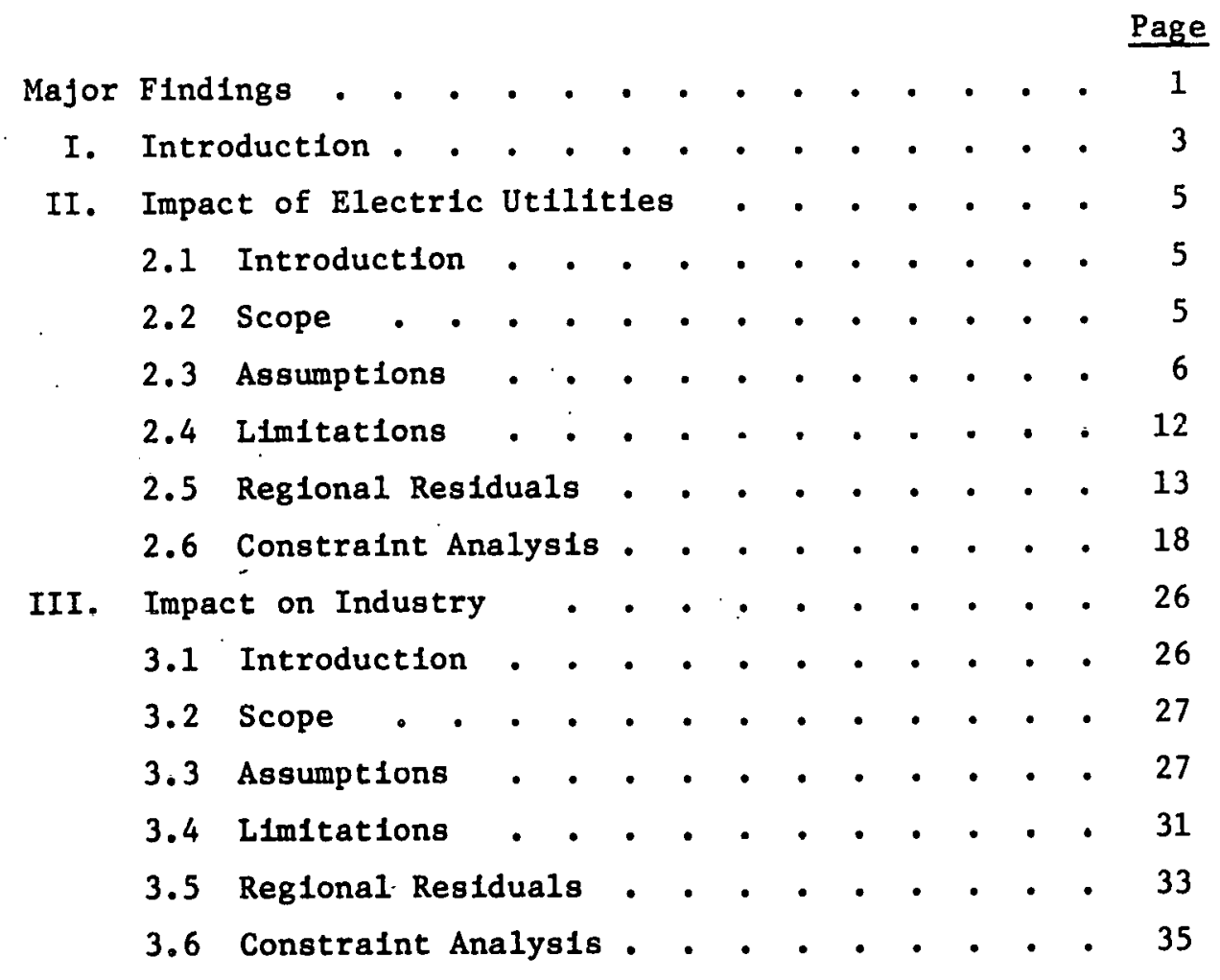

Notes . . . . . . . . . . . . 40

Appendix A . . . . . . . . . . . . • . . 47

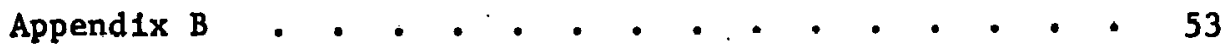


MAJOR FINDINGS

1. The only significant effect of the National Energy P1an (NEP) on solld waste management in electric utilities will be to shift the regional distribution of impacts. Nationally, NEP may result in an increase of ash by $1 \%$, and a decrease in the scrubber sludge disposal area requirement by up to $10 \%$.

2. The Southwest is the only region that may experience significant increases in electric utility solid waste residuals; ash production will increase $20 \%$, and scrubber sludge production by about 33\%. The land areas involved, however, are very small, amounting to annual increases of 30 and 80 acres, respectively. The major offsetting impacts occur in the South Atlant1c, M1dwest, and Central regions, where decreases in both ash and scrubber sludge can be expected. These decreases, however, also Involve very small amounts of land.

3. Based on a nationwide survey of electric utilities planning coal-fired units in the $1980^{\prime} s$, we find that sites are generally of sufficlent size to accomodate on-site ash and FGD system sludge disposal, even where ut1lities are not currently planning FGD systems.

4. Using current technology for fixation of scrubber sludge, ultimate disposal by landfill, and subsequent revegetation, utilities can provide environmentally acceptable methods of scrubber sludge disposal at a small fraction of the total cost of FGD system installation and operation. While the total cost of sludge management may represent up to $20 \%$ of the total FGD system cost, the incremental cost of sludge flxation and landf111, over a base case of unstabilized disposal in an unlined pond, constitutes only some $5 \%-10 \%$ of the total FGD system cost.

5. In light of the above, one can conclude that solid waste management problems should not significantly impede Implemenation of the NEP in the electric utility sector; and in some regions NEP may result in somewhat reduced solid waste generation.

6. A significant fraction of coal using 1ndustries will use FGD systems that produce liquid effluents rather than sludge residuals, with discharge to municipal sewage systems or to water bodies. This will increase dissolved solids concentrations in the recelving waters, but at concentrations that are 
not expected to be of environmental concern except in the arid regions of the west, where any increments to already high dissolved solids concentrations may prove unacceptable, and in such areas where municipal sewage treatment effluents are recycled.

7. Because of the significant cost of sludge transportation, industries that have inadequate land for on-site disposal may incur significant cost penalties for sludge disposal, in addition to facing opposition at the local level to the use of regional or municipal disposal facilities.

8. The largest industrial solid waste impact will occur in the Midwest, accounting for almost one third of the additional sludge residuals due to the NEP. The South Atlantic, Southwest, and Mid-Atlantic regions follow, each accounting for a further $15 \%$ of the national total.

9. In contrast to the utility sector, the question of whether solid waste management problems would pose a significant impediment to the industrial coal conversion goals of the NEP cannot be definitively assessed at the present time. Although we see no general environmental problems arising from the use of currently available technology, only a site specific analysis can fully account for the particular local environmental, economic and Institutional context that industry would face. The key environmental uncertainty is the fate of trace and heavy metals at industrial facflities using liquid scrubbing systems and subsequent liquid waste treatment processes, for which no adequate data currently exists. 


\section{INTRODUCTION}

The objective of this assessment is to identify the degree to which solid waste management problems may impede attainment of the coal utilization objectives embodied in the National Energy Plan. It uses as its basis the Administration's estimates of increased coal utilization attributable to specific NEP Initiatives, and is concerned primarily with the immediate planning horizon through 1985.

The focus of the assessment is limited to solid waste management concerns at the point of coal use, excluding in particular the problems of mining wastes. Thus, in the electric utility sector, the focus is on the impact on scrubber sludge disposal requirements, and, to a lesser extent, on increased levels of ash production due to a slight overall increase in utility coal consumption. 1 In the industrial sector, which accounts for 177 of the total 199 million tons/yr increase in coal use expected under NEP by $1985,{ }^{2}$ the concern is with the rather more significant increases in ash and scrubber sludge production. Because some of the scrubber systems in industry over the next decade will likely result in liquid wastes, discharged to municipal sewers and receiving waters, rather than solid wastes, these systems have also been included in this analysis.

The nature of the solid waste management problems faced by utilities and Industry is quite different, and warrant separate technical discussions. Utilities will require a relatively small number of large sites for waste disposal, but have some flexibility in on-site disposal in areas generally under fewer land constraints. Industry, however, will require a larger number of small sttes, and is thereby more likely to become embrolled in off-site, local solid waste management controversies; on the other hand, industry has greater flexibllity in the choice of FGD technology, where required to meet applicable environmental standards. Specific assumptions tn this regard are discussed later in this report.

In general, the approach has been to establish conservative assumptions in the key areas of uncertainty that materially affect the important impact measures such as the area required for disposal landfill. For example, in the electric utility sector, it is assumed that all new FGD systems w111 be of 
the lime/limestone type, in the knowledge that any unexpected market penetration of regenerative or double alkall systems would lessen computed landfill requirements. 3

The approach also emphasizes analysis of the environmental engineering issues that arise at the site level, in the belief that a proper identification of any constraints that might impede implementation of the NEP will arise not so much from consideration of aggregate waste residuals, as much as from knowledge of Individual utility, industrial and regulatory practices and constraints pertinent to the facility and disposal site level at which decisions affecting coal use will actually be made. 


\subsection{Introduction}

This chapter analyses the impact of NEP on solid waste management problems in the electric utility sector. The analysis proceeds as follows:

- a brief examination of the scope of the problem,

- documentation of the assumptions for quantitative analysis,

- discussion of the limitations of our analysis,

- analysis of the solid waste residuals at the national and reglonal level, focussing on the additional residuals attributable to NEP over a 1985 Base Case, using a comparable definition of Best Available Control Technology (BACT) in both cases,

- discussion of the environmental, land availability and economic issues assoclated with disposal of ash and scrubber sludges.

The conclusions of this analysis can be summarized as follows:

- The additional quantity of ash attributable to NEP by 1985 is insignificant, amounting to an increase of $1 \%$ over a 1985 Base Case.

- Only the Southwest and Western regions experience an increase in scrubber sludge production due to NEP; nationally, a decrease can be expected, possibly as high as $10 \%$, as lower electric demands, resulting from NEP conservation initlatives, reduce coal fired generation primarily in areas using higher sulfur coals.

- The additional solid waste residuals attributable to NEP can be accomodated in an environmentally sound manner using current technology, and without significant additional burden on the consumer.

- Utilities should not experience significant problems in accomodating these NEP attributable increases in solld waste residuals, since on-site disposal is generally possible.

\section{$\underline{2.2}$ Scope}

The scope of the probable Impact of NEP on solid waste management in the electric sector can be estimated from a consideration of the total increase in utility coal use. By 1985, NEP is expected to result in a 16 million tons/year increase in utility coal ut1lization, over a 1985 Base Case ut1lity use of 763 million tons/year. Therefuie, a first order estimate of increased 
solid waste residuals attributable to NEP would be a $2 \%$ increase in both ash and scrubber sludge production, ${ }^{4}$ proportional to this increase in coal use. This suggests that NEP may have little, if any, impact on ut1lity solid waste management, a finding confirmed by the more detalled analysis of residuals presented below.

\subsection{Assumptions}

In order to compute sol1d waste reslduals, assumptions are necessary for the following:

- The characteristics of the coal and the degree to which sulfur and ash in the coal enter the filue gas and ash waste streams.

- The technology used for FGD systems, since this determines the relationship between $\mathrm{SO}_{2}$ in the flue gas and the quantity and quality of the solid waste residuals.

- The physical and chemical characteristics of the sludges and methods used for sludge treatment prior to disposal.

- The method used for sludge disposal.

- The specific land requirements necessary for land disposal.

\subsubsection{Coal Characteristics}

To derive quantitative estimates of solld waste, all ash in coal is assumed to be converted to bottom ash, collected with an efficiency of $100 \%$, and to flyash, collected with an efficiency of $99.5 \%$ (reflecting the assumed use of an electrostatic preclpitator). Although bottom ash is 1ikely to contain a few percent of the sulfur as well, the present analysis simply assumes that all of the sulfur enters the flue gas stream. And although fly ash and $\mathrm{SO}_{2}$ are removed simultaneously in many FGD systems, the present analysis tracks the two separately in terms of weight and volumes. However, since a subotantial quantity of ash 18 currently utilized as construction and fill material, we assume that $11 \%$ of fly ash and $24 \%$ of bottom ash do not enter the waste stream, reflecting the extoring level of ash utilization. ${ }^{6}$

Average heating value, ash content and sulfur content of coals used in each region were assumed to correspond to those currently in use by electric utilities, ${ }^{7}$ but exeluding certain low sulfur coals shipped over long 
distances for blending to meet State Implementation Plan Requirements (SIP's). This definition of coal characteristics corresponds, at the Federal Region level, to locally available coals that will likely be in use under the BACT

provision of the 1977 Clean Air Act Ammendments.

\subsubsection{FGD System Technology}

Lime/limestone systems can be expected to dominate the market for FCD systems at coal fired utility boilers over the next 10 years and the numerical computations assume that all new plants constructed with FGD systems are of this type. ${ }^{5}$ The validity of this assumption is documented on Table 1 which shows a breakdown of FGD systems currently in operation, under construction, or planned, by process. To the extent that regenerative systems, such as the Wellman Lord and Magnesium Oxide processes, make significant market penetrations, the computed results would overstate the volume of solid wastes. Similarly, because the double alkali process produces a sludge of a somewhat higher bulk density, landfill disposal requirements computed on the basis of lime/ limestone bulk densities would also be conservative.

TABLE 1

BREAKDOWN OF FGD SYSTEMS BY PROCESS

\begin{tabular}{|c|c|c|c|c|}
\hline & \multicolumn{2}{|c|}{ New $^{2}$} & \multicolumn{2}{|c|}{ Retrofit ${ }^{2}$} \\
\hline & $\underline{\mathrm{Gw}}$ & . $\underline{\underline{\theta}}$ & $\underline{\mathrm{GW}}$ & \% \\
\hline Lime/Limestone & 27.478 & 93.3 & 4.062 & 67.8 \\
\hline Sodium Carbonate & .759 & 2.5 & .250 & 4.2 \\
\hline Wellman Lord & .375 & 1.2 & .455 & 7.6 \\
\hline Double Alkali & .825 & 2.8 & .277 & 4.6 \\
\hline Magnesium Oxide & - & - & .846 & 14.1 \\
\hline Aqueous Carbonate & - & - & .1 & 1.7 \\
\hline
\end{tabular}

Excluding units planned for which no solection of process has yet been made Source: PEDCO Environmental, "Flue Gas Desulfurization Systems Summary Report," May-June 1977, p. 215.

Given the use of this technology, we have assumed that $80 \%$ of total annual $\mathrm{SO}_{2}$ emissions would be captured by the FGD system, and enter the sludge waste stream. This $80 \%$ removal assumption is consistent with the BACT definition used in the analysis of air pollution impacts of the NEP, ${ }^{9}$ and is premised on a $90 \%$ efficiency of $\mathrm{SO}_{2}$ removal in a system of about $90 \%$ availability. 


\subsubsection{Waste Characteristics}

The lime and IImestone wet scrubbing systems both generate a calcium sulfite/sulfate sludge as the end product. The sludge is produced in large quantities and separation of the water 1s difficult. Untreated, the sludge has the consistency of heavy mud and will remain physically and chemically unstable even after drying. 10

The sludge from lime/limestone FGD units consists primarily of calcium sulfite $\left(\mathrm{CaSO}_{3} \cdot \frac{1}{2} \mathrm{H}_{2} \mathrm{O}\right)$, calclum sulfate $\left(\mathrm{CaSO}_{4} \cdot 2 \mathrm{H}_{2} \mathrm{O}\right)$, unreacted calcium carbonate $\left(\mathrm{CaCO}_{3}\right)$, and the ash stream that is generally added to the sludge. ${ }^{11}$ Table 3 ohowo typliul analyses from a number of upuracling lacilities. The ratio of sulfite to sulfate is important from two standpoints; first is that the sulfite exerts an oxygen demand, and limits some potential disposal options, such as ocean dumping. Second, the ratio determines the bulk density of the sludge product, which in turn determines the landfill space necessary for disposal. The question of trace elements and other chemical properties is taken up in Section 2.6.2.

TABLE 2

Characterlstics of Sludge From Operating $\mathrm{Sn}_{2}$ Srrubbero

\section{Fac111ty \\ (MW)}

\section{Lawrence 4 (125)}

Lawrence 5 (400)

Hawthorn 3 (125)

Hawthorn 4 (140)

W111 County (165)

LaCygne (820)

Cholla (125)

Paddy's Run 6 (70)

Mohave 2 (1.60)

$\frac{\mathrm{He}}{\mathrm{CaSO}_{3}}$
1
1
2
1
5
4
1
9

Helght Percent on a Dry Bas1s

- $\mathrm{x}_{2} \mathrm{H}_{2} \mathrm{O} \mathrm{CaSO}_{4} \cdot 2 \mathrm{H}_{2} \mathrm{O} \mathrm{CaCO}_{3} \mathrm{Ash}$

10

10

20

17

50

40

15

94

2

15

Solids Content of Dewater Sludge WeIght Percent

Source: Ifead1 and Rosenberg, Batelle-Columbus, "Lime/LImestone Sludge D1sposal--Trends in the Ut1l1ty Industry," AIChE 67th Meeting, Washington, D.C., December 1974 . 
$\therefore$.

Normal pond settling with untreated material will probably result in a final settled density of less than 50 percent solids, at which they have low bearing and compressive strength. Untreated sludges show a tendency to rewater after being subjected to dewatering operation if subsequently exposed to rainfall, making unstabilized sludge unsulted for final disposal by landfill. Thus, emphasis has been placed in recent years on methods of sludge treatment to improve its compressive strength and resistence to rewatering. These methods, referred to as "fixation" or "stabilization", make the sludge more sulted to landf 111 disposal and subsequent reclamation and revegetation, reduce the volume of sludge, and minimize the danger of potential environmental problems from leachates infiltrating into the groundwater (as noted below in Section 2.6.2). A number of vendors are currently marketing such treatment systems, most of which produce a stable Inert materlal that has high resistance to the release of toxic metals and soluble specles, and of sufficient compressive strength to support bulldings. 13

However, because of the conslderable varlation in the amount of sludge volume reduction among these proprletory systems, our quantitative analysis will assume a solids content of $50 \%$ by weight, which will result in an overstatement of land acreage for disposal where certain proprietory processes are employed. We shall also assume that each pound of $\mathrm{SO}_{2}$ removed from the stack gas results in 2.83 lbs of sludge sollds, a figure derived from the average of the weight percentages of the mafor sludge constituents shown on Table 2 .

\subsubsection{Disposa1 Options}

Table 3 indicates current sludge disposal practices at plants with FGD systems, with most plants disposing unstabilized sludge in unlined ponds. However, this peittern must be expected to change in the future, with much greater utilization of chemical stabilization (or "ffxation") prior to disposal. One point of uncertainty in this regard is the status of FGD sludge as a "hazardous waste" under the terms of the Resource Conservation and Recovery Act; ${ }^{14}$ EPA's Office of Solid Waste Management has Indicated that it will so classify FGD sludges, whereas State officials in Pennsylvania, Ohio and Kentucky have. indicated that based on leachate constituents they would not classify 1ime;/limestone sludge as hazardous..$^{15}$ Resolution of this difference must awalt promologation of regulations authorized in Section 3001 of this Act, which will set forth the Identifyling characterlstics of hazardous wastes. 
TABLE 3

Current Sludge Disposal Practice by Number of Units

(Corresponding capacity in $\mathrm{Mw}$ in parentheses)

\begin{tabular}{lcccccc} 
& \multicolumn{2}{c}{ Sludge } & & \multicolumn{2}{c}{ Disposal Pond } \\
\cline { 2 - 3 } & $\frac{\text { Stabilized }}{6(2397)}$ & $\frac{\text { Unstabilized }}{\text { Lime }}$ & & $\frac{\text { Lined }}{\text { Unlined }}$ \\
Lime/Alkaline Ash & - & $1305)$ & & - & $8(2702)$ \\
Limestone & $2(367)$ & $5(3400)$ & & $-(1557)$ & $5(2210)$ \\
Sodium Carbonate & - & $1(375)$ & & - & $1(375)$
\end{tabular}

Source: PEDCO FGD Systems Status Report, May-June 1977, Table 11.

If EPA does finally classify FGD sludge as hazardaus, then powers granted EPA to regulate such materlals (via the usual route of state plans being acceptable to the EPA administrator) will strengthen the trend to sludge treatment and landfill disposal, rather than unlined ponding.

This analysis, therefore, assumes that land disposal will be utilized at all electric utility plants. Two other alternatives, offshore disposal and deep mine disposal, have been suggested, but for a number of reasons we regard the former as unlikely and the latter as applicable to only sperial situations. 16 The principal objection to offshore disposal is economic, since on the Northeastern Seaboard, where such an alternarfve mfght be most likely, environmental considerations would require dccp oceau dumping, rather than near coastal dumping on the concinental shelf..$^{1,7}$ Waste disposal in mines is applicable primarily to mine mouth plants; in the eastern regions of the country, however, where groundwater tables are generally high, acid mine drainage would generally result in acidic leaching of waste materials resulting in unacceptably high levels of trace and heavy metal contaiminants.

\subsubsection{Land Requirements}

There is little unf formity In the quanticy of land required for sludge disposal. Table 4 shows land areas utilized at a sample of plants; methods range from an evaporation pond in the arld west to the use of an impounded 
TABLE 4

Typical Land Area Requirements

\begin{tabular}{|c|c|c|c|c|c|}
\hline Plant & Utility & $\underline{M w}$ & $\begin{array}{l}\text { FGD } \\
\text { System }\end{array}$ & $\begin{array}{l}\text { Land } \\
\text { Requirement }\end{array}$ & Comments \\
\hline St. Clair \#6 & Detroit Edison & 170 & Limestone & $\begin{array}{l}\text { (Acres) } \\
12\end{array}$ & $\begin{array}{l}2 \text { years capacity } \\
\text { settling pond }\end{array}$ \\
\hline Reid Gardner & Nevada Power & 375 & $\begin{array}{l}\text { Sodium Car- } \\
\text { bonate }\end{array}$ & 50 & $\begin{array}{l}5 \text { acre settling pond } \& \\
45 \text { acre evaporation pond }\end{array}$ \\
\hline LaCygne $\# 1$ & $\begin{array}{l}\text { Kansas City } \\
\text { P \& L }\end{array}$ & 820 & Limestone & 160 & - \\
\hline $\begin{array}{l}\text { Widows Creek } \\
\quad \# 8\end{array}$ & TVA & 550 & Limestone & 100 & $\begin{array}{l}30 \mathrm{ft} \text { dike, storage } \\
\text { for } 7 \text { years }\end{array}$ \\
\hline Sherburne & $\begin{array}{l}\text { Northern } \\
\text { States Power }\end{array}$ & 1390 & Limestone & 62 & $\begin{array}{l}\text { Clay lined Settling } \\
\text { pond, } 45 \mathrm{ft} \text {. deep }\end{array}$ \\
\hline Colstrip & $\begin{array}{l}\text { Montana } \\
\text { Power Co. }\end{array}$ & $72 \mathrm{C}$ & $\begin{array}{l}\text { Lime/Alkaline } \\
\text { Ash }\end{array}$ & 137 & $\begin{array}{l}520 \text { acre-ft holding pond } \\
\& 2218 \text { acre-ft disposal }\end{array}$ \\
\hline Paddy Run $\$ 16$ & $\begin{array}{l}\text { Loulsville } \\
\text { Gas \& Electric }\end{array}$ & 65 & Carbide LIme & 10 & Offsite Landf $111^{\text {pond }}$ \\
\hline 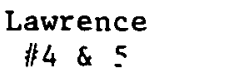 & $\begin{array}{l}\text { Kansas Power } \\
\text { and Light }\end{array}$ & 525 & Limestone & 48 & - \\
\hline Cholla \#1 & Arizona Public & $e^{115}$ & Limestone & $\begin{array}{c}\text { Not } \\
\text { Available }\end{array}$ & Evaporation Pond \\
\hline $\begin{array}{l}\text { Bruce Mans- } \\
\text { field } 1-3\end{array}$ & $\begin{array}{l}\text { Pennsylvania } \\
\text { Power \& Light }\end{array}$ & 2505 & Lime & 900 & $\begin{array}{l}420 \mathrm{ft} \text {. Impoundment, } \\
\text { Intire valley of } 1400 \\
\text { acres purchased }\end{array}$ \\
\hline
\end{tabular}

ravine In Pennsylvania to create what in effect is a sludge lake. Because of this variability in climate, topography and disposal practice a statistically significant relationship between plant size, climate, land requirement and disposal method, based on actual utility experience, could not be determined. Instead, we derive in Appendix $A$ an analytical method of computing acre-ft of sludge storage volume.

This methodology estimates that for a typical plant burning $3.5 \%$ sulfur coal and with $80 \% \mathrm{SO}_{2}$ removal, the storage requirement computes to $.47 \mathrm{acre} \mathrm{ft} / \mathrm{Mw} / \mathrm{yr}$ for sludge, and . 16 acre $\mathrm{ft.} / \mathrm{Mw} / \mathrm{yr}$ for ash. Assuming a $32 \mathrm{ft}$. depth and a $1000 \mathrm{Mw}$ plant, this translates to a total disposal area of 590 acres over the 
30 year lifetime of the plant. This is conservative in that chemical fixation will result in a substantial volume reduction, and landfill disposal is not necessarily limited to a $32 \mathrm{ft}$. helght. Plants burning low sulfur coal would require proportionally less area for sludge disposal.

\subsection{Limitations}

The principal limitation of the analysis is the restricted time horizon of 1985. Because of the long construction lead time for new utility plants, NEP can do little to change the capacity $\mathrm{mlx}$ in the electric sector by 1985; beyond this date, howevcr, the ull and gas replacement program is likely to have more impact, with larger Increases of conl cepaclly, over, say, a 1990 base case. It follows that increases in solid waste residuals beyond 1985 attributable to NEP would be more significant. Beyond 1985, however, advanced FGD systems producing efther a useful byproduct or using regenerable scrubbing agents will likely become more widespread; these systems provide an inherently satisfactory solution to any solld waste problems that do emerge. Larger NEP increases in coal use beyond 1985 will thus be offset by a lower overall rate of solld waste generation.

Since we assume that all of the sulfur removal is by use of FGD systems, a second limitation of our analysis concerns the possible use of coal cleaning in conjunction w1th FGD systems. However, since any change in the definition of BACT would apply to both Base and NEP cases, any redefinition of BACT to Include coal cleanlng would therefore result in NEP impacts at the point of combustion that are even smaller than those Indicated in our computations of Section 2.5, although offset by roughly similar increases that would be generated at the location of the coal cleaning plants.

Moreover, the characteristics of the washing process are specific to almost the particular coal seam in question, with wide varlations in pyritic sulfur content and physical properties, thus making any specific assumptions applicable

to regional averages questionable. ${ }^{18}$ In any event the additional quantity of solid waste produced at the coal cleaning plant would result in waste disposal problems which are similar to those encountered at the boller location. This analysis does not address these problems because of their dependence on a specific site. 
Finally, since the residuals are directly related to the level of coal use in each region, a clear limitation of this study is that only the levels and distributions predicted by PIES model are considered quantitatively. ${ }^{19}$

\subsection{Regional Residuals}

Table 5 displays the computation of ash residuals by Federal Region consistent with the preceeding assumptions and the methodology of Appendix A. The States in each Federal Region are identified in Figure 1. The following points should be noted:

- Nationally, the increase in ash residuals is about $1 \%$, with a similar increase in land requirement for disposal.

- Even though total utility coal consumption under NEP increases by 16 million tons per year (or $2 \%$ over the Base Case) generation from coal under NEP stays virtually unchanged (a decrease of about 0.1 percent). This is because the NEP results in a shift to the use of higher ash content coals, which, for the same total generation, requires a higher tonnage of coal to be mined.

- The Southwest and West are the only regions experiencing significant. NEP attributable increases in coal fired generation; most other regions experfence decreases. But since locally available coal in the Southwest has a higher than average ash content, this is the only region to experience a substantial NEP increase in ash residuals (a 20\% increase over the Base Case). However, because land is relatively abundant in both the West and Southwest, and because the absolute amounts of acreage are small (an additional 5 and 30 acres per year, respectively, due to NEP), the regional impact is not significant.

Table 6 shows the computations for scrubber sludge residuals, by Federal Region. In contrast to the computations for ash residuals, for which the PIES model results could be used directly for estimates of total coal use (which governs ash production), the PIES model cannot estimate the 
TABLE 5

Ash Residuals in the Electric Sector

1985 Base Case Ash

FEA Ash Landf111

Region

Nw-Eng.

$\mathrm{NY} / \mathrm{NJ}$

M1d-At1

S. -Atl

Midwest

S. West

Central

N-Cntrl

West

N. -West

National

Total

41.51

744.39

7.53

33.87

1.89

105.24

9.94

178.32

10.35

7.77

2.68

185.57

139.30

48.12

1.27

.81

22.70

14.50

9.25

.52

Trom PIES Run A 148542C, Table 17

brom PIES Run A 158569C, Table 17
1985 NEP Increments

Ash

Aok Landfill Gegeration

(MMT/YR) (ACRES/YR) $10^{9} \mathrm{Kwh} \mathrm{b}$

.03

2.22

93.57

.02

.97

$-.07$

.35

$-2.90$

$-.38$

$-1.33$

$-15.99$

417.75

447.03

$-.21$

$-8.98$

187.32

112.64

58.55

45.57

14.57

1.66

$-3.73$

40.14

$-.44$

29.85

$-18.56$

$-.18$

$-7.93$

$-8.50$

.30

$-3.29$

17.12

$-.25$

$-4.55$

$-7.17$

.48

8.53

$-1.65$ 


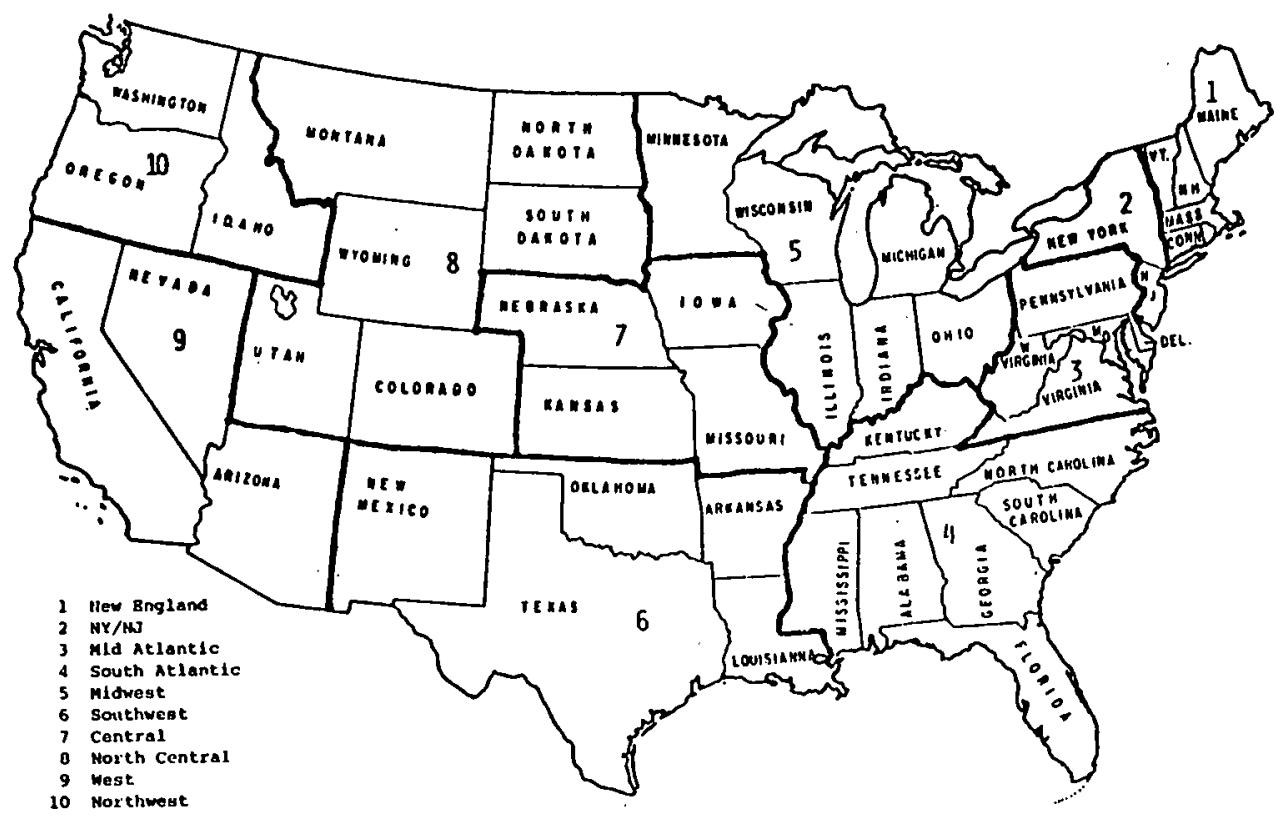

Figure 1. Definttion of Federal Regions.

degree of scrubber use by region in the Base Case. ${ }^{20}$ Consequently, the Base Case computations of Table 6 are based on scrubbers currently in use plus existing FGD system commitments (as per the EPA-PEDCO data base) ${ }^{21}$ plus an estimate of additional scrubber use in the years 1982-1985 that would result from the implementation of the BACT provision of the Clean Air Act. ${ }^{22}$ The 1985 increments attributable to NEP are based on the difference in coal generation, by region, between the PIES model estimates for 1985 NEP and the Base Case, with the additional assumption that any difference in these two cases would occur in plants that have scrubbers. This would tend to overstate the impact on sludge residuals, since some of the difference would occur at plants that do not have FGD systems, and which therefore would not affect scrubber sludge residuals. The analysis thus provides a maximum estimate of impact, with actual Impacts 11kely to be somewhat less than those computed.

Inspection of Table 6 leads to the following observations:

- Total national land requirements for sludge disposal will decrease by about $10 \%$ under NEP, with roughly similar decreases in total sludge volumes and weights. 
TABLE 6

Scrubber Sludge Residuals in the Electric Sector

\begin{tabular}{|c|c|c|c|c|c|c|c|c|c|c|c|}
\hline $\begin{array}{l}\text { FEA } \\
\text { Region } \\
\end{array}$ & $\begin{array}{l}\text { Siudge } \\
\text { Sollds } \\
\text { (Rn/yr) } \\
\end{array}$ & $\begin{array}{l}\text { Wet } \\
\text { sludge } \\
\text { (ngigriys) }\end{array}$ & $\begin{array}{l}\text { S1 udge } \\
\text { Volume } \\
\text { (meve ft/gr) }\end{array}$ & $\begin{array}{l}\text { Sludge } \\
\text { Landfili1 } \\
\text { (Acres:/yr) }\end{array}$ & $\begin{array}{l}\text { Total } \\
\text { Land } \\
\text { Comitited } \\
\text { (Acres) } \\
\end{array}$ & $\begin{array}{l}\text { Sludge } \\
\text { Sol1ds } \\
\text { (nerT/yr) }\end{array}$ & $\begin{array}{l}\text { Wet } \\
\text { S-udge } \\
\text { (ErT/yr) } \\
\end{array}$ & $\begin{array}{l}\text { Sludge } \\
\text { Volume } \\
\text { (MrCo. ft./yr) }\end{array}$ & $\begin{array}{l}\text { Sludge } \\
\text { Landf11.1 } \\
\text { (Acres/yr) }\end{array}$ & $\begin{array}{l}\text { Total } \\
\text { Land } \\
\text { Committed } \\
\text { (Acres) }\end{array}$ & $\begin{array}{l}\text { Ceneration } \\
\text { MMtRwh/yr }\end{array}$ \\
\hline $\mathrm{Nu}-\mathrm{Eng1}$ & .13 & $.2 \pi$ & .27 & 5 & 150 & .08 & .16 & .16 & 3 & 90 & 2.22 \\
\hline $\mathbb{N} / \mathrm{NJ}$ & .19 & . 3E. & .38 & 7 & 210 & .03 & .07 & .07 & .1 & 30 & .97 \\
\hline Mid-At1 & 1.63 & 3.26 & $\$ .27$ & 63 & 1890 & -.11 & -.22 & -.22 & -4 & -120 & -2.90 \\
\hline S.-At1 & 4.55 & $9.1]$ & $\subseteq .16$ & 177 & 5310 & -.75 & -1.51 & -1.52 & -29 & -870 & -15.99 \\
\hline Mddrest & 4.96 & 9.93 & 5.99 & 193 & 5740 & -.48 & -.96 &.- .36 & -18 & -540 & -8.98 \\
\hline S. Hest & 2.06 & 4.13 & 4. 16 & 80 & 2400 & .72 & 1.45 & 1.45 & 28 & 840 & 40.14 \\
\hline Central & 1.88 & 3.77 & 3.79 & 73 & 2190 & -1.16 & -2.33 & -2.33 & -45 & -1350 & -18.56 \\
\hline$N$-Cntrl & .96 & 1.91 & 1.92 & 37 & 1110 & -.12 & -.25 & -.25 & -4 & -120 & -8.50 \\
\hline West & .41 & .82 & .83 & 16 & 480 & .16 & 32 & .32 & 6 & 180 & 17.12 \\
\hline N. -West & 0.00 & 0.00 & 0.00 & 0 & 0 & -.10 & -.20 & -.20 & -3 & -90 & -7.17 \\
\hline $\begin{array}{l}\text { Natlonal } \\
\text { Total }\end{array}$ & 16.78 & 33.57 & 34.63 & 651 & 19530 & -1.73 & -3.47 & -3.49 & -65 & 1950 & -1.65 \\
\hline
\end{tabular}


- At a regional level, some areas of the country experience increases in sludge residuals, some experfence decreases. The land requirement in the Southwest increases by some $35 \%$, consistent with the more rapld increase in coal generation in this region. The additional 840 acres of land that must be committed to sludge disposal (over the lifetime of the facilities in place by 1985), however, are not significant in view of the very large sites typical of utilities in this region (a subject discussed below in Section 2.6.1).

- The largest decreases in land requirement occur in the Central, South Atlantic, and Midwestern regions; these occur because the total coal generation in these regions also decreases under NEP, and, consistent with our assumptions, all such decreases are assumed to occur at plants with FGD systems. Coal generation under NEP decreases because total electricity generation by 1985 under NEP decreases by some 7\% (In terms of Btu consumption), in consequence of the conservation and load management provisions of NEP.

- By the same token as the sludge Increases in the Southwest are of no significant concern, so will the decreases in land requirement in the other regions provide little significant benefit. Recall from Section 2.3.5 that a $1000 \mathrm{MW}$ plant requires about 600 acres of land for sludge disposal over its lifetime; thus the 3090 acre saving in the 6 regions showing a land decrease under NEP implies that at most $5 \mathrm{GW}$ of coal capactty would be affected. That represents $2 \%$ of the 258 GW 1985 Base Case coal capacity in these 6 regions.

Not only are the incremental NEP impacts sma11, and in some regions. beneficial, but also the total quantity of electric utility scrubber sludge generated in 1985 under the future envisaged by NEP 1s quite small. The 30 million tons a year of ut 11 ty scrubber sludge should be contrasted with other activities generating sludge wastes: ${ }^{23}$

$\begin{array}{lr}\text { Municipal Sewage Sludge } & 55 \text { million tors in } 1980 \text { (est.) } \\ \text { Phosphate Rock Slime } & 760 \text { mililon toris in } 1970 \\ \text { Acid Mine Drainage Sludge } & 8 \text { million tons in } 1970 \\ \text { Gypsum from Fertilizer } & \\ \text { Manufacturing } & 28 \text { million tons in } 1973 \\ \text { Taconite Tallings } & 1100 \text { million tons in } 1971\end{array}$




\subsection{Constraint Analysis}

While the analysis of residuals by region is helpful in assessing the overall scope of the solid waste management problem, it is the assessment of the implications of such impacts that is key to any credible judgment as to the degree to which solid waste problems constrain the implementation of the NEP. Thus we consider, at the scale of site implementation, the key potential constraints; land avallability, environmental problems, and the economic penalties of mitigating measures.

\subsubsection{Land Avatlability}

Land requirements for sludge disposal are not so excessive as to be considered a cruclal constraint. The sharp growth in the number of thrnwaway lime/Limestone systems now planned suggests that most utilities have coped with the sludge disposal problem quite well, and certainty there is little evidence that land avallabllity w111 be a problem in most areas of the country. Even in the Northeast, where there have been few committments to FGD systems and where one might expect greatest difficulties in site selection in view of high population densities, review of recent utility and power pool planning reports suggests that the utilities have still been able to assemble sites of 1000 to 3000 acres to accomodate future coal fired plants in the $1980^{\prime} \mathrm{s}$ and early 1990's. This makes them of sufficient size to accomodate sludge disposal on-site for units planned at these sitcs. 24

By way of example, consider the New York Power Pool, and the sites currently under study by the utilities for coal-fired base load units expected in the 1980's and early 1990's, ${ }^{25^{\prime}}$ as shown in Table 7. Of the six sites identified in the most recent site inventory, one already is planned to include FGD. The remaining five plants are planned to burn low sulfur coal to meet existing NSPS and SIP requirements without scrubbers, yet even these plants appear to have adequate land area for waste disposal for throwaway lime/ 1imestone FGD systems. Howcver, it is perhaps doubtful that the Sheriden site could accomodate a sufficlent space for more than one FGD over its entire 1ife and the Cayuga site may be 1li-sulted for a large sludge pond (although might well be able to accomodate a landf1ll operation). 
TABLE 7

Siles in New York ${ }^{a}$

\begin{tabular}{|c|c|c|c|c|c|}
\hline & $\begin{array}{c}\text { Capacity } \\
\text { MW } \\
\end{array}$ & $\begin{array}{c}\text { Expected } \\
\text { Service Date }\end{array}$ & $\begin{array}{c}\text { Site Size, } \\
\text { Acres } \\
\end{array}$ & $\begin{array}{l}\text { Necessary Area } \\
\text { for Waste Dis- } \\
\text { posal w1th FGD }\end{array}$ & $\begin{array}{l}\text { Anticipated } \\
\text { Problems for on- } \\
\text { slte disposal. }\end{array}$ \\
\hline Cayuga & 850 & 1983 & 915 & $\begin{array}{l}\text { (Acre8) } \\
398\end{array}$ & Terrain difficultiea \\
\hline Somerset & 850 & 1983 & 955 & 398 & Appears sufted \\
\hline Sheriden & $\begin{array}{l}850 \\
850\end{array}$ & $\left.\begin{array}{l}1985 \\
1987\end{array}\right\}$ & 986 & 796 & Appears sulted \\
\hline $\begin{array}{l}\text { Pomfret } \\
\text { (alternate } \\
\text { to Sheriden) }\end{array}$ & $\begin{array}{l}850 \\
850\end{array}$ & $\left.\begin{array}{l}1985 \\
1987 \\
\text { Early }\end{array}\right\}$ & 1054 & 796 & Appears sulted \\
\hline Sterling & $\begin{array}{l}600 \\
600\end{array}$ & $\begin{array}{l}1990^{\prime} \mathrm{s} \\
\text { Early } \\
1990^{\prime} \mathrm{s}\end{array}$ & 2800 & 562 & $\begin{array}{l}\text { Hilly terrain, but } \\
\text { Impoundments possible }\end{array}$ \\
\hline $\begin{array}{l}700 \text { MN PASNY } \\
\text { Staten Island }\end{array}$ & 700 & 1982 & & & FGD system planned \\
\hline
\end{tabular}

\footnotetext{
a Source: New York Power Pool, note 25

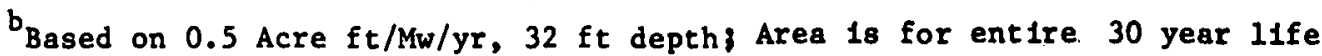
of the units indicated.

CBased solely on a brief review of the applicable quad sheets, and not on any detalled geotechnical assessment.
}

In order the confirm these findings at a national scale, we conducted a national survey of utilities that presently have plans for coal fired units In the early 1980's. The results of this survey are displayed on Figure 2, which shows the site size as a function of planned capacity at that site, Identifled by Federal Rellabllity Council Reglon. The cross-hatched area Indicates the range of necessary land requirement for sludge and ash disposal over the lifetime of a plant assuming .63 acre-ft/Mw/year for storage depths of $32 \mathrm{ft}$ and $16 \mathrm{ft}^{26}$ All of the planned facilitles surveyed have adequate acreage to accomodate on-site FGD waste disposal. Many of the utility engineers indicated that contingency plans existed if FGD systems were to be required. And many other facllities were planning to exploit some unique site specific characteristic, from reclamation of old, nearby 


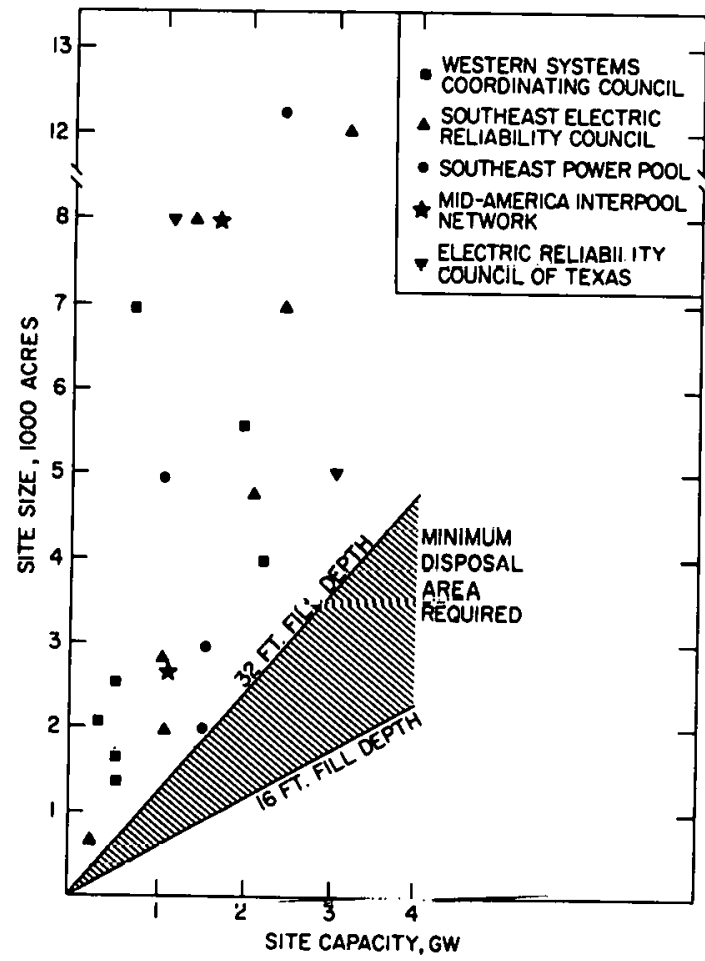

Figure 2. S1ce size by plant capacity and rellability counc1l reglon. 
strip mines to the construction of a $45 \mathrm{ft}$ revegetated berm to mitigate noise and aesthetic impacts of the facllity itself.

These results indicate that on-site FGD system waste disposal is technically feasible even at plants which do not presently plan to use such systems and would only in rare cases pose a sertous problem. Assembly of large land areas for coal burning plants also seems well within the capabilities of the utilities. We conclude, therefore, that availability of sludge disposal sites will unlikely constrain increased coal utilization in the electric utility sector.

\subsubsection{Environmental Issues}

There is a considerable research and monitoring effort at existing facilities to assess the potential environmental problems from ash and scrubber sludge disposal. The general conclusions to date include the following:

- Sludge liquors (the overflow of a simple ponding operation) contain concentrations of heavy metals and dissolved solids that may pose some threat under certain circumstances;

- Leachates from unfixed sludge disposal sites or unlined ponds contain heavy metal and trace element concentrations that are generally below levels consldered to be hazardous, but with dissolved solids contents that are still much higher than what would be acceptable in groundwater used for drinking water;

- Impermeable disposal pond linings may be necessary in some cases to afford protection to nearby groundwater;

- Chemical fixation of the sludge reduces the concentration of major species (although not of trace elements) in leachates by a factor of 2 to 4 , in addition to providing other benefits such as volume reduction, decreased permeability and greater compressive strength. 27 
These general conclusions are exemplified by the data of Table 8; column (1) shows the concentration in the sludge liquor from an eastern coal limestone scrubber operation; (corresponding to the overflow of a simple pond) 28 Column (2) the untreated leachate at the same plant; Column (3) the groundwater contaminant IImits of the State of New York, ${ }^{29}$ one of the few states to have set specific IImits for contaminant concentrations entering groundwater; 30 Column (4) the 1962 US Public Health Service Drinking Water Standards, which for these elements marked with an asterisk colncide with the 1975 EPA Standards promulgated under the Safe Drinking Water Act ${ }^{31}$ and Column (5) the leachatc concentrations after fixation by the Dravo Chemfix process. Note that Arsenic, Lead, Selenium, Chloride, Fluoride, Sulfate and Total Dissolved Solids (TDS) concentrations in the liquor are substantially in excess of the groundwater contaminant limits and drinking water standards; that only sulfates and TDS exceed the standards in the leachate; and that sulfates and TDS exceed the ifmits even after fixation.

The general conclusion that pond linings, chemical fixation and landfill disposal provide adequate environmental protection does not imply, however, that the potential for environmental problems is absent. Considerable research 1s still underway to address the key uncertainties. These include:

- The length of time over which leachates are of concern, since provision of lined ponds designed to provide un impermeahle barrier for soveral decades may be overly conservative under certain sludge fixation methods; conversely, a 30 year liner life may be inadequate for unstabllized sludge that may be unstable indefinately.

- The degree to which alternatives to the 11me/limestone FGD system results in sludges that pose a different potential for leaching (the double alkali process, fur example, produces a sludge that has physical properties making 1 more sulted as landfill, but has a higher soluble salt content than $11 \mathrm{me} / 1$ mestone bludge).

- The fate of trace elements over long time spans.

- The permanence of stabllization, especially under microbial action. 
TABLE 8

Comparison of Chemical Constituents ( $\mathrm{Mg} / \mathrm{l}$ )

(See Text for Source)

(1)

(2)

$\begin{array}{ll}\text { Liquor } & \begin{array}{l}\text { Leachate } \\ \text { Untreated }\end{array}\end{array}$

Arsenic

Cadmiun

Chromium

Copper

Lead

Mercury

Selenlum

Zinc

Cloride

Floride

$\mathrm{SO}_{4}$

TDS

$\mathrm{pH}$

\subsection{4}

0.003

$\underline{0.09}$

0.01

$\underline{0.25}$

$<\underline{0.05}$

$\underline{0.08}$

0.2

$\underline{2300}$

$\underline{6.2}$

10,000

$\underline{15,000}$

8.3

$$
0.01
$$

$<0.001$

0.003

0.01

0.01

$<0.00005$

0.006

0.045

120

$<0.2$

$\underline{1,200}$

2,400

$\underline{5.0}$
(3)

New York State limit for groundwater contaminants (Schedule II)

\section{1}

0.02

0.1

0.4

0.1

$-$

0.02

0.6

500

3.0

500

1,000

$6.5-8.5$
(4)

U.S. Public

Health Service Leachate,

Drinking Water after fixation by

Standards Chemfix Process

$.05 *$

$.01 *$

$.05 *$

1.0

$.05 *$

$.002 *$

$.01 *$

5.0

250

1. 4-2.4*

250

500
(5)

0.006

$<0.001$

$<0.001$

0.005

$<0.001$

$<0.0005$

0.002

0.065

60

0.2

650

1,500

6.01

Underlined values exceed the Drinking Water Standards.

*

Also the new EPA Standard under the Safe Drinking Water Act of 1975 .

Vegetation cannot generally be established on FGD or coal ash disposal areas without additional preparation and unstabilized sludge may not have sufficient compressive strength..$^{32}$ However, sludge fixation and a 2 to $3 \mathrm{ft}$. layer of soil overburden will usually suffice to aid in the establishment of vegetation, and thus reclamation of disposal areas is within current technical abilities.

In conclusion, given proper engineering judgment in the selection of disposal sites, the treatment process used, the decision as to whether or not to line an intermediate ponding operation, and the ultimate mode of disposal, environmentally sound disposal of throwaway lime/limestone scrubber sludges will generally be possible. 


\section{$\underline{2.6 .3 \text { Economic Issues }}$}

Although the costs of chemical fixation of sludge and holding pond linings are substantial, they can become small in comparison to the costs of sludge transportation. ${ }^{34}$ Table 9 1llustrates the relative importance of various subsystem costs. These estimates are consistent with recently reported total cost estimates in actual practice. ${ }^{35}$ A range of $\$ 5-\$ 15$ per ton of dry solids would be a representative figure, equivalent to an additional generation cost of about .6 to $2.0 \mathrm{mills} / \mathrm{kwh}$. In terms of capital requirements, the sludge disposal system, Including all necessary land aquisitions, will represent between 10 and $30 \%$ of the total FGD system capital cost requirement. The total sludge disposal cost of .6-2.0 mills/kwh should be contrasted with the overall cost of an FGD system, which can be expected to be in the range of 5 to $13 \mathrm{mills} / \mathrm{kwh}$. Thus, sludge disposal will account for between 15 and $20 \%$ of the total FGD system cost. More importantly, the additional cost incurred by chemical fixation and proper landfilling disposal represents only about an additional $5 \%-10 \%$ of total FGD system cost. For a typical residential user of $500 \mathrm{kwh} /$ month, total FGD system costs are thus $\$ 30-\$ 78$ per year; of wh1ch proper sludge disposal accounts for $\$ 4-\$ 12$; and of which only $\$ 1.20-\$ 2.40$ represents the cost of chemical flxation. 
TABLE 9

IMPACT OF VARIOUS SUBSET SLUDGE DISPOSAL OPTIONS

ON THE ANNUALIZED COST OF SLUDGE DISPOSAL ${ }^{a}$

\begin{tabular}{|c|c|c|c|}
\hline & M111s/KWH & $\$ /$ Dry Ton & \$/Wet Ton \\
\hline Unlined Pond/No Fixation & 0.463 & 7.54 & 4.53 \\
\hline Synthetic Lining . & 0.451 & 7.35 & 4.41 \\
\hline Fixation & 0.204 & 3.32 & 2.00 \\
\hline Trucking - 5 miles & 1.023 & 16.67 & 10.00 \\
\hline Trucking - $10 \mathrm{mlles}$ & 2.046 & 33.33 & 20.00 \\
\hline Trucking - 15 miles & 3.069 & 50.00 & 30.00 \\
\hline Pumping - 5 miles & 0.224 & 3.65 & 2.19 \\
\hline Pump1ng - 10 miles & 0.336 & 5.47 & 3.28 \\
\hline Pumping - 15 miles & 0.448 & 7.30 & 4.38 \\
\hline Retrofit & $(0.040)^{b}$ & $(.65)$ & $(.39)$ \\
\hline Low Sulfur & $(0.337)$ & $(7.17)$ & $(4.30)$ \\
\hline
\end{tabular}

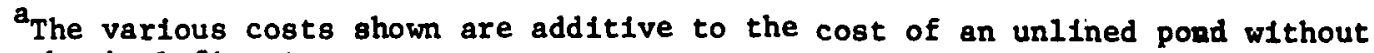
chemical fixation.

$b_{\text {Numbers in parentheses are negative. }}$

Source: PEDCo, note 21. 


\subsection{Introduction}

This chapter examines the impact of the NEP on solid waste management in industry. As in the case of the utflity sector, we proceed as follows:

- a brief examination of the scope of the problem,

- documentation of the assumptions for quantitative analysis,

- discussion of the Iimitations of the analysis,

- an analysis of the solid waste residuels at the national and regional level,

- a discussion of any constraints to solid waste disposal, addressing in particular the questions of land avallability and environmental impacts.

The conclusions of this analysis can be summarized as follows:

- Ash production at coal burning industrial installations will approximately double by 1985 as a result of the NEP, as measured over the corresponding 1985 Base Case.

- The production of FGD system sludge at coal-burning industrial facilities will increase at most by $60 \%$ nationally as a result of NEP, again as measured nver a correspunding $198 \mathrm{~b}$ Base Case.

- Significant additional sludge disposal problems must be anticipated for Industries that have inadequate 1and for on-site disposal, and who may therefore incur high transportation cost penaltieg for lisposal at offsite, regional or municipal waste disposal stites. The exact extent of these difficulties, however, can only be assessed on a case-by-case basis at the site level.

- As a result of these difficulties many industries will utilize FGD systems that produce a liquld rather than solid waste, generally resulting in the discharge of sodfum sulfate into muntctpal sewers and receiving waters.

- The concentrations at which sodium sulfate would enter the environment from such systems is generally low, and unlikely to be of concern except in the arld west, where any increase in salinity may be unacceptable. 


\subsection{Scope}

Of the total 199 million tons/year additional coal use expected by 1985 as a result of the NEP, 177 million tons/year will occur in the Industrial sector. ${ }^{36}$ Nationally this increase implies about an almost threefold increase in coal use by industry over the 1985 Base Case. 37 Ash disposal by coal-using industrles w1ll increase roughly in proportion to total coal use. Sludge disposal increases would be less than proportional because smaller Industrial facilities would 11kely be under less stringent emission limitations under currently expected definitions of BACT.

The bounds of the problem at the regional level are illustrated on Table 10, which shows the compound annual growth rate and total increase in coal use, under both the 1985 Base Case and NEP. In relative terms, coal use in Industry under NEP w111 grow fastest in the West, the Southwest and New England; in absolute terms, however, (Col. 3) the Southwest and the key Industrial areas of the Midwest and East (Regions 3,4 and 5) will be the most significantly affected. It is in these areas, therefore, that solld waste management problems due to NEP are expected to be most acute.

\subsection{Assumptions}

Estimation of the solid waste impacts of increased industrial coal use stemming from the NEP is based primarily on assumptions with regard to the following 1tems:

- Level and location of increased industrial coal use in each region of the country as a result of NEP, as well as the level of coal use expected in the absence of any plan.

- Characteristics of coals used by various industrial facilities, in particular their average heating value, sulfur content, ash content, and ash composition.

- Characteristics of the combustion technologies used by industrial sources, In particular the fractions of ash and sulfur in coal that are directed to environmental control systems.

- Alr pollution control regulations applicable to the types and sizes of Industrial combustors used in each region of the country.

- Extent to which environmental control technologies are ut1lized by Industrial sources for the control of sulfur and particulate 
TABLE 10

PIES MODEL PREDICTIONS OF GROUTH RATES IN INDUSTRIAL COAL USE ${ }^{a}$

\begin{tabular}{|c|c|c|c|}
\hline \multirow{2}{*}{$\begin{array}{l}\text { FEA/EPA } \\
\text { Reg1on }\end{array}$} & \multicolumn{2}{|c|}{$\begin{array}{l}\text { Compound Annual } \\
\text { Growth Rate } \\
\text { (percent) }\end{array}$} & \multirow{2}{*}{$\begin{array}{l}\text { Absolute Increase } \\
\frac{1985 \text { NEP over } 1985 \text { Base }}{\left(10^{12} \text { Btu/yr }\right)}\end{array}$} \\
\hline & Rase Case & Inttiatives & \\
\hline 1. New England & 0.2 & 34.7 & 86.9 \\
\hline 2. $\mathrm{NY} / \mathrm{NJ}$ & 3.2 & 19.3 & 282.5 \\
\hline 3. Mid-Atlantic & 1.5 & 11.0 & 553.1 \\
\hline 4. South Atlantic & 5.7 & 16.4 & 597.0 \\
\hline 5. Mid-West & 6.1 & 11.1 & 615.0 \\
\hline 6. South West. & 10.2 & $41 . \dot{9}$ & $i 155.2$ \\
\hline 7. Central & 1.0 & 8.3 & 84.9 \\
\hline 8. North Central & 7.2 & 22.1 & 264.6 \\
\hline 9. West & 15.3 & 46.9 & 370.4 \\
\hline 10. North West & 10.3 & 22.3 & 123.8 \\
\hline U.5. 'Total & 5.1 & 16.6 & 4133.3 \\
\hline
\end{tabular}

Excluding Metallurgioal Coal. 
emissions, and the characteristics of these technologies in terms of their collection efflciencles, energy penalities and the quantity and chemical/physical nature of sludges, liquids or other waste streams emanating from them.

\subsubsection{Levels and Location of Future Industrial Coal Use: Levels of future} industrial coal use were taken to be the values projected for 1985 by the Project Independence Evaluation System (PIES) model for both Base Case and NEP inftiatives scenarios. ${ }^{38}$ The Base Case reflects a situation with no new government initiatives to stimulate increased use of coal, while the NEP Case reflects the effect of the entire National Energy Plan on industrial coal use. The location of Industry is based on historical trends, and allocates future industrial growth to areas that are currently the important industrial centers.

\subsubsection{Combustion Technology and Coal Characteristics: All coal utilized} In the Industrial sector is assumed to be combusted in a manner characterisitic of Industrial boiler facilities. Although combustion characteristics for nonboilers may differ from this, such differences depend on specific industrial processes, and are generally not well understood or quantified at the present time. In terms of solid waste impacts, however, this assumption is conservative for two reasons: (1) coal use in non-boilers is likely to result in lower solid waste generation as a result of less stringent air pollution control regulations, and (2) some portion of coal wastes is likely to be retained in the process product (e.g., retention of sulfux by cement in coal-fired cement kilns).

To derive quantitative estimates of solid waste residuals, similar assumptions to those used in the electric sector are used, with all coal sulfur entering the flue gas stream as $\mathrm{SO}_{2}$ (See Section 2.3.1). However, unlike the utility sector, we make the conservative assumption that all collected ash must be disposed of, since no rellable data on utilization of ash from industrial boilers is available. 
The average heating value, ash and sulfur content of coals used in industry was also derived in a manner similar to that described for the electric sector (Section 2.3.1), again reflecting the assumption that locally available coal will be most likely under implementation of BACT. The ash and sulfur contents assumed for the analysis of industrial residuals are displayed on Appendix Tables 17 and 18, respectively.

\subsubsection{Air Quality Scenarios}

Consistent with NEP analyses of air pollution impacts, we assume that best available control technology w1ll apply to industrial coal use in all new large boilers (greater than $25 \mathrm{MW}$ ). This is interpreted to mean an $80 \%$ reduction in potential $\mathrm{SO}_{2}$ emissions. Sulfur dioxide emissions from new small boilers (1ess than $25 \mathrm{MW}$ ) are assumed to be 1 imited to $1.51 \mathrm{bs} / \mathrm{m}$ llition Btu of coal input to the boiler. BACT for particulate control is assumed to limit emissions to $0.05 \mathrm{lb} / \mathrm{million}$ Btu for both large and small boilers, implying a $99.5 \%$ collection efficiency for flyash, well within the performance of current particulate removal technology. For existing sources we assume State Implementation Plan requirements, consistent with other NEP air pollution analyses. The assumed use of FGD systems in each region for each of the major categories (existing, new large, new small) is documented in Appendix B, Table 13, and is again consistent with the NEP air pollution analysis. 40

These assumptions for BACT are assumed to apply to both the 1985 Base Case and the NEP case, cunsistent with the premise that RACT w1.11 be implumented uitler the provisions of the 1977 Clean Air Act Amendments.

\subsubsection{Control Technology}

Control of particulate matter is assumed to bc univelsally required for any factility burning coal. It is assumed that the control levele called fur are achleved elther by dry collection of fly ash (e.g., using electrostatic precipitators or baghnuses), or by wet collection (scrubbing), possibly in conjunction with a iry uschanieal cullector. All of these represent currently avallable technologies. The specific cholce of control technology depends on a number of factors including whether or not desulfurization technology is also required. 
Consistent with other NEP analyses, the present analysis also assumes that a flue gas desulfurization (FGD) system is the technology of choice for complying with BACT. The detailed assumptions used to derive a quantitative estimate of this appear in Appendix B, Tables 14-16. The FGD system is assumed to be either a dual alkali system, producing a wet solid sludge for disposal, or a chemical liquid scrubbing system, producing a liquid waste stream for disposal that is discharged to municipal sewers or receiving waters after neutralization. ${ }^{40}$ These are most representative of the systems now used with industrial boilers. According to the best available estimates of Industrial FGD use, liquid scrubbing systems are approximately three times more prevalent than sludge-producing systems (Table 11). Regenerative FGD systems that recover a useful byproduct are currently employed in selected industries (such as sulfuric acid manufacture) but not considered a likely choice for typical industrial boller applications. The added solid waste impacts of industrial FGD systems will thus be distinct in form as well as in magnitude from those of electric utility FGD installations, where the prevalent technology is a lime/limestone system producing a wet sludge.

Because of the difficulties of predicting a precise mix of the two major FGD system types, the computation of residuals is for two extreme cases; one case in which all industries are assumed to use liquid scrubbing systems, a second case in which all industries are assumed to be using double-alkali systems producing a sludge waste.

\subsection{Limitations}

One limitation of the analysis is that the solid waste impacts of technologies for the control of sulfur and/or particulate emissions other than FGD are not considered. Alternatlve technologies for sulfur control could include fluidized bed combustion (FBC) and low-Btu gasification. The former is a promising technology which captures sulfur directly in the boiler rather than in a downstream control system, and may recover it as a useful byproduct. However, FBC is not yet commercially available and is not likely to be used significantly before 1985. 41 Low-Btu gasification is another currently avallable technology that first transforms coal into a gaseous fuel. Sulfur is removed in the form of hydrogen sulfide rather than as $\mathrm{SO}_{2}$, and is 
TABLE 11: SUMMARY OF SOME EXISTING INDUSTRIAL FGD SYSTEMS

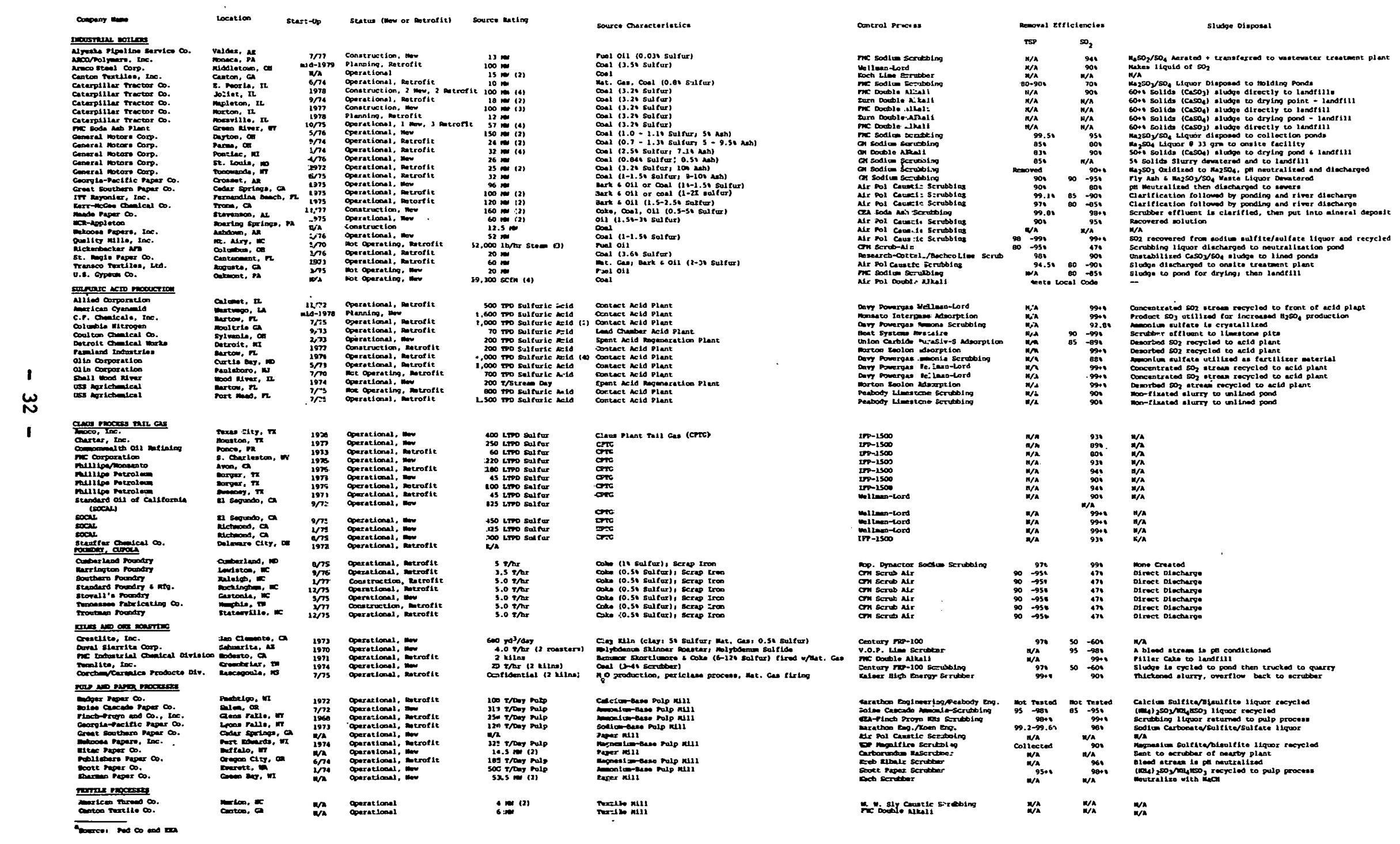


typically recovered as elemental sulfur, thereby eliminating the need for FGD. The high relative cost of gasification technology, however, has prevented its substantial use in this country. This will likely continue to be the case in the foreseeable future, according to a recent study, by Battelle Memorial Institute. ${ }^{42}$ But with the incentives for coal utilization provided in the NEP, low-Btu gas and FBC may well appear more attractive relative to FGD technologies. The ensuing effects on solid waste impacts, however, are not considered in this analysis. 43

The assumption of a single set of coal characteristics for each Federal region represents a limitation on the analysis since other characteristics would affect the level of environmental control needed, and, therefore, the amount and type of solid waste generated. In most cases the average sulfur and ash content per unit energy of locally avallable coal is quite pimilar to the average for all coals actually used in each reglon at the present time. In general, the assumption of a locally avallable coal is a conservative one since this leads to a situation in which desulfurization technologies, with their ensuing solid waste impacts, are used to the maximum extent. The range of impurities in local coals, however, can be considerable (e.g., a factor of two for sulfur in many regions), and this could affect any quantitative results should future average regional characteristics shift away from present values.

Finally, since solid waste generation is related directly to the level of coal use, a clear limitation of this study is that only the levels and reglonal distributions predicted by PIES are considered quantitatively.

\subsection{Regional Residuals}

Quantitative estimates of the regional solid waste residuals are displayed on Table 12.

Ash Residuals: Columns 1 and 2 show the estimated dry weight of ash collected from the combustion of coal. Some 14 million tons must be disposed of nationally in 1985 in the absence of the NEP, while the Increased use of coal anticlpated by the NEP would triple this requirement to about 44 million tons per year. Since much of this ash might be.collected or temporarily stored in a holding pond prior to disposal, the actual welght of the ultimate waste could be as high as twice these tonnages since typlcal sedimentation and clarification systems yield a sludge that is generally 40 to $60 \%$ solids by 
TABLE 12

1985 RESIDUALS BY ?EGION ASSUMING EACT (in million tons/year)

1985 Dry Ash Production ${ }^{\text {a }}$

Base Case NEF Increase

1. New England

2. $\mathrm{NY} / \mathrm{NJ}$

3. Mid-Atlantic

4. South Atlantic

5. Mid-West

6. South West

7. Central

8. Nortb Central

9. West

10. Nortr West U.S. Total

\begin{tabular}{rr}
.017 & .306 \\
.456 & 1.791 \\
2.567 & 3.722 \\
2.313 & 3.747 \\
6.135 & 3.624 \\
1.038 & 12.590 \\
.485 & .494 \\
.571 & 1.528 \\
.16 .9 & 1.730 \\
.657 & 1.150 \\
\hline 14.451 & 30.362
\end{tabular}

\begin{tabular}{|c|c|}
\hline \multicolumn{2}{|c|}{$\begin{array}{l}\text { Maximum Production of FGD } \\
\text { Dissolvet Solids }\end{array}$} \\
\hline Base Case & NEP Increase \\
\hline .004 & .093 \\
\hline .202 & .710 \\
\hline .454 & 1.257 \\
\hline .457 & 1.135 \\
\hline 2.899 & 2.033 \\
\hline .057 & .894 \\
\hline .139 & .387 \\
\hline .050 & .187 \\
\hline .016 & .171 \\
\hline .041 & .970 \\
\hline 4.319 & 6.964 \\
\hline
\end{tabular}

\begin{tabular}{cc}
\multicolumn{2}{c}{$\begin{array}{c}\text { Maximum Production of FGD } \\
\text { Wet Sludges }\end{array}$} \\
\hline Base Case & NEP Increase \\
\cline { 1 - 1 } .010 & .253 \\
.542 & 1.908 \\
1.217 & 3.342 \\
1.226 & 3.045 \\
7.772 & 5.452 \\
.153 & 2.399 \\
.374 & 1.041 \\
.139 & .503 \\
.043 & .460 \\
.111 & .262 \\
\hline 11.587 & 18.665
\end{tabular}

\footnotetext{
Actual wet weight will be approximated twice as great for ash that is ponded prior to disposal; this is most likely to be the case where a sludge producing FGD system is also required.

${ }^{\text {Assumes }}$ i 1.80 lb wet sludgeilb of sulfur removed, characterisitic of calcium sulfite/sulfate mixtures from dual alkali systems dewatered to $50 \%$ solids.

${ }^{c}$ Assumes $4.441 b$ dissclved solid/lb silfur removed, characteristic of soidum sulfate from an alkaline liquid scrubbing system; all industrial systems are assumed to be of this type.
} 
weight. Regionally, the greatest disposal needs will occur in the Southwest (Region 6) which is estimated to have the greatest increase in industrial coal use (See Table 10). Locally available coal in the regton also contains approximately twice as much ash as in other regions of the country, further adding to the ash disposal problem. The overriding requirement in all regions will be the availability of economically and environmentally acceptable sites for the disposal of collected ash.

Residuals from dissolved solids-producing FGD systems: Columns 3 and 4 show the maximum estimate of the dissolved solids that would result if all industrial FGD systems were of the liquid scrubbing type, with complete oxidation to sulfates. Geographically, the most substantial impacts would occur in the Midwest (Region 5) as well as in the Middle Atlantic and South Atlantic regions of the country (Regions 3 and 4 ). It is here that the high level of coal use combined with the high sulfur content of local coals produces the greatest quantity of sulfur-bearing wastes to be disposed of.

Residuals from sludge-producing FGD systems: These same regions are also the most significantly affected under the alternative assumption that sludgeproducing rather than liquid-producing FGD systems are universally employed In the Industrial sector (Columns 5 and 6 ). Here, quantitative estimates of maximum solid waste impacts are derived assuming a dual alkali system, which is the most prevalent sludge-producing system currently used by industry. For this technology, the environmental disposal problem is similar to that faced by electric utilities using lime/limestone; 1.e., the waste sludge is one containing calcium sulfate, calcium sulfite and limestone with an overall solids content of about $50 \%$ by weight. As in ut1lity FGD systems, disposal of Industrial FGD sludge can be environmentally acceptable if accomplished in the manner elaborated in Section 2.3.5, and if sufficient land is available for disposal.

\subsection{Constralnt Analysis}

Application of the two major categories of FGD system likely to be in use by industry over the next decade will be constrained by rather different considerations of solld waste management. For systems producing a sludge, the key concern will be the avallability of disposal sites, whereas for the liquid scrubber systems, the key issue concerns the impact of dissolved solids discharges Int.n municipal sewer systems and natural water bodies. 


\subsubsection{Land Ava1lab1lity}

In contrast to the utility sector, where, as we have seen in Section 2.6.1, sites are frequently of a size that will allow on-site sludge disposal, the ability of industry to dispose of sludge on-site will be much more limited. An exact answer would require analysis at the individual site level, an analysis that goes beyond the scope of this preliminary assessment.

One can, however, derive estimates of the maximum impact at the county level by comparing the magnitude of the sludge produced by industrial FGD systems with municipal refuse and municipal sewage treatment plant sludges produced in the same county. To the extent that the sludge is unstabilized, which, as noted in Section 2.3.3, implies that it would be unsuited for direct landfill disposal, the appropriate comparison is with the quantities of municipal wastewater treatment plant sludge generated at the county level, since a common disposal method would be indicated. Order of magnitude computations for the Northeast, reported elsewhere, 44 indicate that the increases in sludge attributable to NEP by 1985 represent between 100 and $500 \%$ of the wet weight of such municipal treatment plant sludges. Given the well known problems of sludge disposal at municipal sewage treatment plants, 45 this suggests the presence of strong incentives to provide stabilization of the industrial FGD sludges prinr to dioposal (ur to use a liquid waste producing FGD system).

For a stabilized sludge, that could readily be disposed of in a landfill operation, the appropriate measure of impact is the ratio nf additinnal eludge weiglit actilbutable to the NEP to the weight of municipal refuse generated. For the Northeast, the area where solid waste management problems are most severe, order of magnitude computations indicate that the maximum increases at the county level are in the range of 1 to $20 \% .46$ This suggests that the additional FGD sludge could probably be accommodaled. However, the economics of such stabilization at the industrial plant scale are not well known; and off $=8$ ite regional processing centers to serve a number of industries would incur ofgniffcant organizational and institutional obstacles.

\subsubsection{Environmental Issues}

The environmental impacts of industrial FGD sludge disposal by landfill are quite similar to those indicated for the utility sludges in Section 2.6.2. In general one should note, however, that the sludge produced by the typical 
industrial double alkali system has somewhat different physical and leaching characteristics to lime/limestone sludges.

For a number of reasons it is likely that industries that cannot accommodate on-site sludge disposal would move to a liquid scrubbing system. Discharge could be to an existing wastewater treatment system, to a sewer system or a natural watercourse. Whenever off-site sludge disposal is necessary, the cost of sludge transportation dominates the disposal economics, as 1llustrated earlier on Table 9. Beyond the economic considerations, the "hassle" associated with involvement in local solid waste management problems provides a powerful incentive to use a liquid system, especially where an industry already has other liquid waste streams for which it must provide treatment and neutralization.

The maximum impact of these dissolved solids discharges at the county level have been estimated for the Northeast. 47 The results indicate a 1985 increase in dissolved solids concentrations in municipal sewer systems attributable to NEP in the range of $20 \mathrm{ppm}$ to $1100 \mathrm{ppm}$, under worst case assumptions of all industries electing to use such liquid FGD systems. The fact that these concentration increases vary by orders of magnitude from county to county again indicates that more detailed study is warranted.

As to the environmental significance of the dissolved solids (DS) levels indicated, this again is a matter that can only be addressed at the site level. In areas where municipal sewage treatment plant effluents are being considered for recycling (as on Long Island) even small increases of dissolved solids may be unacceptable, since DS will gradually accumulate after many cycles of re-use, and are removed only at great cost and with great difficulty. Similar restrictions may apply in Western areas where already high total dissolved solids levels are of concern. In and of 1tself, however, a higher DS content of municipal sewage will not affect the usual sewage treatment processes, 48 and the lons of concern, sodium and sulfate, are nelther regarded as hazardous at the concentrations indicated, nor do they constitute algal nutrients that may be of concern where sewage is discharged to lakes and estuaries. However, high sulfate levels (beyond $500 \mathrm{ppm}$ ) may be regarded as unacceptable for a drinking water supply. 
It is clear, however, that some industries may discharge directly into water bodies, rather than sewage systems, where dilution volumes are such that Increased dissolved solids concentrations attributable to industrlal discharges would be much less than for DS in sewage. For the Northeast, the likely annual average DS increases in the Connecticut, Hudson and Merrimack Rivers can be computed to $0.71,1.47$ and $3.21 \mathrm{mg} / \mathrm{l}$, respectively, levels that are unlikely to be of concern. During periods of low flow, however, the increases may be more significant. This computation rests on assignment of the FGD system DS discharges from counties to the corresponding river basin, using the total annual basin runoff as the dilution volume. 50 But a corresponding computation for the Colorado and Rio Grande River basins results in a dissolved solids concentration increase of about $25 \mathrm{ppm}$, an increase that in view of already serious concerns over the salinity of these rivers may well be unacceptable. 51 These computations, however, are an upper bound in that all industries requiring FGD systems are assumed to elect a system producing a liquid waste. Of course, in these arid areas, an evaporation pond might be used as an alternative disposal strategy; but this option raises the question of the acceptability of additional consumptive water use by evaporation.

An important uncertainty is that the fate of trace and heavy metals in such industrial liquid FGD systems is unknown; and until the data are improved some caution should be exercised, since the nature of the discharge may in fact be much less benfign than a cunstderation of only dissolved onlide might Indiçate.

As to the regulatory. aspects of such discharges, 1t should be noted that under provisions of the 1972 Amendments to the Water Pollution Control Act, Industries whose wastes are discharged to publicly owned treatment works (PoTW) are required to pretreat their wastes to render harmless substances which would Interfere with the operation of the POTW. ${ }^{52}$ Spectfic pretreatulent standards exist for such substances. However, since disanlved sollds and sulfates will not generally affect normal POTW operation, and since an industry that discharges Into a POTW does not require a permit under PL $92-500,53$ there does not appear to be a regulatory obstacle to discharge of FGD system DS provided that the oxidation of sulfite to sulfate is complete. If that process is incomplete, the 
sulfite may exert an oxygen demand, in which case treatment operations would be affected. In any event, municipal laws may require a permit even where Federal Law does not so mandate. 54

In the event of a direct discharge into a water body, industries are required to obtain permits. However, in the EPA development document for the Effluent Limitation Guidelines for the Steam-Electric Power Generating Point source category, ${ }^{55}$ sulfites, sulfates and total dissolved solids (TDS) were rejected as pollution parameters requiring regulation on the basis of their not being controllable. This decision was upheld when EPA published steam electric power generating point source category pretreatment standards for existing sources. 56 EPA has noted the objectionable character of these pollutants and has identified air pollution devices for $\mathrm{SO}_{2}$ removal as one of their sources. But, at the present time, sulfates and TDS are not. regulated for steam electric power plant discharges, direct or pretreated, for the aforementioned reasons. 57 Thus it seems unlikely that smaller Industrial bollers would be treated any differently.

\subsubsection{Economic Issues}

There are only very isolated data for the cost of industrial FGD systems, and no reliable reports on the sludge treatment and disposal cost component. At this point, then, very little can be sald quantitatively about the economic trade-offs that exist between various FGD systems and waste management options. Precise answers would require a site and industry specific analysis, including the assessment of existing treatment practices for other liquid and solid waste streams that may provide scale incentives to move to either a liquid or sludge producing FGD system. Potential difficulties in off-site sludge disposal arrangements, including the extent of transportation penalties for disposal at reglonal or municipal facilities, would also need to be evaluated on a case by case basis. 
1. This may be masked, however, if Best Available Control Technology (BACT) to be implemented under the 1977 Ammendments to the Clean Air Act, results in the substitution of Interfor and Appalachian coals for Western Coal, which have different ash contents.

2. Executive Office of the President, Energy Policy and Planning, "Replacing Oil and Gas with Coal and other Fuels in the Industrial and Utillty Sectors," June 2, 1977, p. III-3.

3. The alternative of making exact estimates for the level of market penctration among the currently avallable systems wnuld impart lu che analysis a spuriouo level of prertision that wuld be quite misleading in view of the uncertainties that prevall.

4. Assuming that all of the additional coal use attributable to NEP is subject to BACT.

5. This assumption is consistent with the judgement of many utilities; the Commonwealth Edison Company, in testimony to the EPA Public Hearing on New Coal Fired Steam Generators $\mathrm{SO}_{2}$ Emissions, May 26, noted

"....We further believe that the limestone wet slurry scrubber technology is the only one which could be built today with any hope of satisfactorily reliable operation. Our recent experience with the proposals for a 425 megawatt (MW) installation at our Powerton Station supports this position. The RFP's were issued to six vendors with no constraints imposed as to scrubber technology. We received four responses, with all but one vendor bidding either a limestone or lime wet slurry system. That one vendor bld a regenerative system which has not heen tested at demonstration scale."

6. Based on data from the National Ash Association.

7. As based on 1975 FPC data on coal deliveries to Steam Electric Plants. "Annual Summary of Cost and Quality of Steam Electric Plant Fuels, 1975" FPC Staff Report, May 1976.

8. In 1975, for example, 5000 tons of $0.6 \%$ sulfiur coal were dellvered to New York. Utilities from Colorado for blending purposes (FPC, note 7, supra, p. 44).

9. EPA, Cffice of Planning and Fvaluation and Executive Office of the l'resident, Energy Policy and Planning "Air Pollution Impacts of the 0il and Gas Replacement Program in the Industrial Sector" June 13, 1977.

10. The sodium alkali and double alkali processes also generate a calcium sulfite/sulfate sludge, but of a different composition than the limestone systems. The result of the double alkali processes is a sludge that is drier and more stable with better handling characteristics than that from. a lime or limestone process. 
11. For a review of ponding practices, see e.g., Radian Corp "Evaluation of Lime/Limestone Sludge Disposal Options", Report to EPA, Nov. 1973 (NTIS $P B$ 232022). It should be noted that the practice of disposing the ash together with the FGD sludge is quite widespread, and thus many of the potential leachable elements may originate from the ash rather than the sludge itself. Moreover, although ash ponds have been in operation for many years, there has been 11 ttle concern with environmental contamination either by dissolved solids or by trace elements. On the other hand, due to the very slow rate of leachate movement through soils, it could be many years before a groundwater contamination problem would be discovered by some user downstream of the site.

12. In contrast to these properties of lime/limestone sludges, preliminary results for double alkali scrubbers indicate that unfixed, dewatered sludge resists rewatering and forms an air-dried skin soon after disposal-See e.g., J. FitzPatrick "Control of Leachate from Double Alkali $\mathrm{SO}_{2}$ Scrubber Sludge Disposal" Jolnt Power Generation Conference, Long Beach California, Sept. 1977.

13. For a good summary description of these processes, see e.g., Environmental Sclence and Technology, Vo1. 9,7, p. 623, July 1975 ("The Stab1lization Game").

14. Relevant federal legislation pertaining to waste disposal includes the Solid Waste Disposal Act of 1965, as amended, the EPA Guidelines for the Land Disposal of Solid Waste, and the recently passed (Oct. 1976) Resource Conservation and Recovery Act (RCRA). The RCRA amends both the Disposal Act and the Guidelines; however, regulations and programs which it authorizes will not be promulgated or implemented until at least 18 months after enactment, i.e., March 1978.

15. See Lunt et al, note 16 , Infra, p. 191.

16. At the present time no FGD sludge is disposed of in this manner, and a recent comprehensive assessment by the Inter-agency Energy Environment R\&D Program concluded that in addition to the usual need for careful case-by-case evaluation, economic feasibility of the most promising environmental option was far from clear cut (R. R. Lunt et al, "An Evalution of the Disposal of the Flue-Gas-Desulfurization Wastes in Mines and the Ocean: Initial Assessment," EPA-600/7-77-051, 1976, U.S. Environmental Protection Agency, Office of Research and Development, Washington, D.C.) The key problem is the oxygen demand of the sludge, which depends on the proportion of calclum sulfite to calcium sulfate in the sludge. Other potential problems include (1) Inadequate initial dilution of the sulfiterich sludge would result in sulfite concentrations in excess of lethal doses for flsh under laboratory conditions. The effects of sludges under field conditions has not been studied in detail. (2) The solubility of trace metals within the sludge matrix is not known, but during the dumping process the concentration of several trace metals suspended in seawater would exceed recommended levels. (3) Unconsolidated sludge materials dumped on the sea floor would significantly alter the environment of benthic organisms, resulting in substantial population changes, and Suspended sludge particles in transit through the water column may have detrimencal effecte on fish and other organisms. 
17. The continental shelf in the New York Bight, for example, is already undergoing oxygen stress. In 1976 a massive kill of fish and benthic organisms with a catastrophic effect on commercial fisheries occurred off the New Jersey coast. The causes for this oxygen depletion covering thousands of bottom square miles are not thoroughly understood, but may be related to an unusual bloom of phytoplankton plus the combined effects of pollution from the Hudson estuary, sewage sludge dumping and dredge spoil dumping. See e.g., F. W. Barvenik, et al, "An Analysis of Time Dependent Factors Leading to Anoxic Conditions within the Middle Atlantic Bight during 1976," BNL-21943. Brookhaven National Laboratory, Upton, New York 11973 (Special Symp. Conf., International Decade of Ocean Exploration (IDOE), Washington, D.C.) October 15, 1976.

18. See e.g., J. Cavallaro, et al."Sulfur. Redurtion Potenllal ot the Coals of the United Stares" Bureau of Mines Report RI 8118, 1976.

19. The two PIES model runs used by the Administration for estimating the 1985 impacts of the NEP initiatives, over a 1985 base case that corresponds to business as usual with no new significant government incentives, are numbered Al48542C (Base Case) and A158569C for the NEP Case.

20. For the Base Case, the problem is that the PIES model cannot accurately simulate the mix of high sulfur coal plants with scrubbers plus low sulfur coal plants without scrubbers that corresponds to the actual situation, where in each region the utilities make their own, and usually different, choices.

21. PEDCO Environmental, "Flue Gas Desulfurization Systems Summary Report," May-June 1977, p. 215.

22. This was based on an examination of the most recent Electric Reliability Council reports to FPC; all coal fired plants listed as coming on line in the years 1982-1985 were assumed to be subject to BACT, and, consiatent with the assumptions nf thio repull, would be fitted with srrubbero. The BAC'I adjustment, therefora, is the toral of such capacity minus such plants as listed in the PEDCO report as already having a commitment to scrubbers.

23. FEA "Coal Conversion Program, Final Environmental Impact Statement" Vol. 1, May 1977, p. IV-31.

24. That is not to say, of course, that such sites are necessarily liconoed by state and federal agenries withoul dlfficulty; the point is more to 11lustrate that land availability in and of itself does not appear to represent a crucial constraint.

25. Report of Metuber Eleclrlc Systems of the New York Power Pool pertinent to Section $149 b$ of the Public Service Law of New York State, Vol. 2, April 1, 1977.

26. This is based on .47 acre $\mathrm{ft} / \mathrm{Mw} /$ year for sludge disposal plus $.16 \mathrm{acre} / \mathrm{ft} /$ Mw/year for ash dispusal, as indicated in section 2.3 .5 for $80 \% \mathrm{SO}_{2}$ removal and $3.5 \%$ sulfur coal. It is obviously conservative for plants scrubbing low sulfur western coal. 
27. See e.g., P. P. Leo and J. Rossoff "Control of Waste and Water Pollution from Power Plant Flue Gas Cleaning Systems; First Annual R\&D Report", EPA-600/7-76-018, Oct. 1976.

28. Adapted from various tabulations in Lunt et a1, note 16, supra.

29. As per New York State Groundwater Classification and Standards, Part 703.

30. See e.g., J. P. Woodyard "The Regulation of Flue Gas Desulfurization Sludge Disposal--Present and Proposed Approaches", Joint Power Generation Conference, Long Beach, California, Sept. 1977.

31. Public Law 93-523; Interim Regulations proposed by EPA in March 1975 (40 Federal Register 11991, March 14); promulgated Dec. 1975.

32. There is considerable research underway to investigate the growth of vegetation directly on flyash disposal sites without the need for additional soll overburden. Research in the U.K. has found that several grasses and vegetables were tolerant of flyashes from alkaline type coals and several studies have been conducted at the Morgantown Energy Research Center on the use of flyash for strip mine reclamation (see e.g., J. P. Kappand and D. W. Gilmore "Soil-making Potential of Power Plant Flyash in Mined-land Reclamation" Third Ash Utilization Symposium IC-8640, U.S. Bureau of Mines, p. 258-279).

33. One conclusion of the first Annual R\&D Report of the Inter-Agency EnergyEnvironment R\&D Program perhaps bears mention here (Leo and Rossoff, note 27 , supra) "... In summary, chemical treatment by the methods evaluated by this study (Chemfix, Dravo, IUCS) do not tend to reduce leachate concentrations of trace elements but do reduce the concentrations of the major specles by a factor of 2 to 4 relative to untreated sludge leachates. However, other effects resulting from chemical treatment, such as reduced permeability and superior disposal placement treatment, are considered significant in reducing the release rate of all the constituents to the soll beneath the treated wastes."

34. PEDCO Environmental "Flue Gas Desulfurization Process Cost Assessment" Report to EPA, May 1975.

35. Specific Cost Estimates are to be found in the 1976 FGD Symposium Procedings EPA 600/2-76-136a (May 1976); and McGlamery et al "Detailed Cost Estimates for Advanced Effluent Desulfurlzation Processes" EPA 600/2-75-006, Jan. 1975.

36. Executive Office of the President, note 2, supra.

37. The coal consumption figures in industry for 1975,1985 Base Case, and 1985 NEP Case are 63, 101 and 278 million tons/yr, respectively.

38. Runs $158569 \mathrm{C}$ and $148542 \mathrm{C}$, respectively.

39. EPA, Office of Planning and Evaluation and Executive Office of the President, Energy Policy and Planning, "Air Pollution Impacts of the 0il and Gas Replacement Program in the Industrial Sector" June 13, 1977; our assumptions correspond to Case 2 of page 14. 
40. A typical example is a process using a sodium sulfite solution to scrub $\mathrm{SO}_{2}$ from the flue gas. This forms a solution of sodium bisulfite which is ${ }^{2}$ then bled off and neutralized by the addition of sodium carbonate (soda ash), regenerating sodium sulfite. The chemistry is such that half of this can be recycled to the scrubber while the remaining half represents spent solution to be discharged. This waste stream is typically aerated to convert sodium sulfite to sodium sulfate in order to reduce the chemical oxygen demand (COD) of the waste. Table 11 shows that the waste stream is then often discharged directly to a river or sewer system. The oxygen demand of this discharge depends on the level of sodium sulfite still remaining. If the conversion of sulfite to sulfate is complete, the dissolved solids level of of the waste stream represents the principal wastewater pollutant associated with this technology.

41. "Application of Fluidized Bed Technology to Industrial Boilers," Exxon Research and Engineering Co. Report to FEA, ERDA and EPA, January 1977.

42. "Synthetic Fuels in the Future of Energy," in Proceedings of the 5th National Symposium, ASME Air Pollutton Control Division, June 1977.

43. For a preliminary qualitative assessment of the ramifications of FBC on Solid Waste Management, See e.g., "Preliminary Assessment of the Health and Environmental Impacts of Fluidized Bed Combustion of Coal as Applied to Electric Utility Systems" Argonne National Laboratory, Feb. 1977.

44. T. Le, P. Meier and E. Rubin "Coal Ut1lization in the Northeast, Vol. VIII: Solid Waste Management Issues and Impacts" BNL 23603, Brookhaven National Laboratory, Upton, NY, February 1978.

45. The controversial disposal of sewage treatment plant sludge from major Northeastern cities by ocean dumping is indicative of these problems, requiring expensive alternative solutions as such dumping is phased nut.

16. Le, et a1, note 44 , supra.

47. Ibid.

48. To the extent that the oxidation of sulfite to sulfate is incomplete (see note 40 , supra), however, some impact on municipal sewage treatment plants may be expected, since any remaining sulfite exerts an oxygen demand. Also, under anaerobic conditions, reduction of sulfaces to hydrogen sulfide may be uf concern. However, such anaerobic conditions in sewer systems are indicative of other problems in municipal waste management and would not be due to increased sulfate discharges.

49. With regard to sulfate, the National Academy of Sciences Recommendations to EPA on drinking Water and Health (Federal Register, Monday, July 11, 1977) noted "No adverse health effects have been noted for concentrations of sulfate in drinking water less than about $500 \mathrm{mg} / 1 \mathrm{iter}$. Diarrhea is the only physiological effect observed at concentrations greater than 1,000 $\mathrm{mg} /$ liter. The taste threshold for sulfate in water lies between 300 and $400 \mathrm{mg} / 1$ iter for most persons, but some are able to detect as little as $200 \mathrm{mg} / 1$ iter." And for Sodium, the Academy noted "Specification of a 'no-observed-adverse-health-effect' 1.evel in water, for which the effect 
is associated with total dietary intake and for which usual food intake is already greater than a desirable level, is impossible. Since adult fluid Intake averages 1.5-3 liters/day, sodium intake from drinking water represents less than 10 percent of the habitual total intake of $3000-4000 \mathrm{mg}$ so long as the sodium content of the water does not exceed $200 \mathrm{mg} / 1 \mathrm{iter}$. Adverse health effects may be anticlpated with sodium concentrations in water greater than $20 \mathrm{mg} / 1$ iter only for that special risk group restricted to total sodium intake of $500 \mathrm{mg} / \mathrm{day}$, because $1 \mathrm{t}$ is not feasible to reduce intake from food below $440 \mathrm{mg} /$ day. For this group, whose diets must be medically supervised, knowledge of the sodium ion concentration of the drinking water permits prescription of bottled water low in sodium when necessary."

50. As per North Atlantic Regional Water Resources study, Appendix C, U.S. Corps of Engineers, North Atlantic Division, 1972.

51. The normal DS range in the Colorado and Rio Grande Rivers is 100-2000ppm (see e.g., discussion in Water Quality Criteria", Report by National Technical Advisory Committee to the Secretary of the Interior, Apr. 1968.)

52. FWPCA 402 (b)-(f).

53. Federal Environmental Law, E. L. Dolgin and T. G. P. Gullbert, ed, West Publishing Co. (1974).

54. However, the POTW 1tself requires an EPA discharge permit, the terms of which may be violiated by pollutants introduced into the POTW. In such cases the discharges into the POTW may be subject to restrictions. (FWPCA $4.02(\mathrm{~h})$ ). In some POTW's users may be required to pay a "proportional share" of the construction, Operation and maintenance costs of the facility. (FWPCA 204 (b) and $402(\mathrm{~b})(9)$. )

55. U.S. EPA, Development Document for Effluent Limitations Guide for the Steam Electric Power Generating Point Sources Category", 10/74.

56. Federal Reg1ster 42:56, pp. 15690-15696, 2/23/77.

57. Note that removal of TDS from waste water 1s one of the more difficult and expensive treatment procedures, particularly when applled to sodium, calclum and potassium ions. Processes for TDS reduction include reverse osmosis, distillation, ion exchange and electrodialysis, all very expensive. 
THIS PAGE

\section{WAS INTENTIONALLY LEFT BLANK}


Append1x A

A Methodology for Electric Utility

Residuals Estimation 
This Appendix sets forth the algorithms used to compute the residuals from coal-fired power plants. The dimensions of each term are noted in brackets.

1. Notation

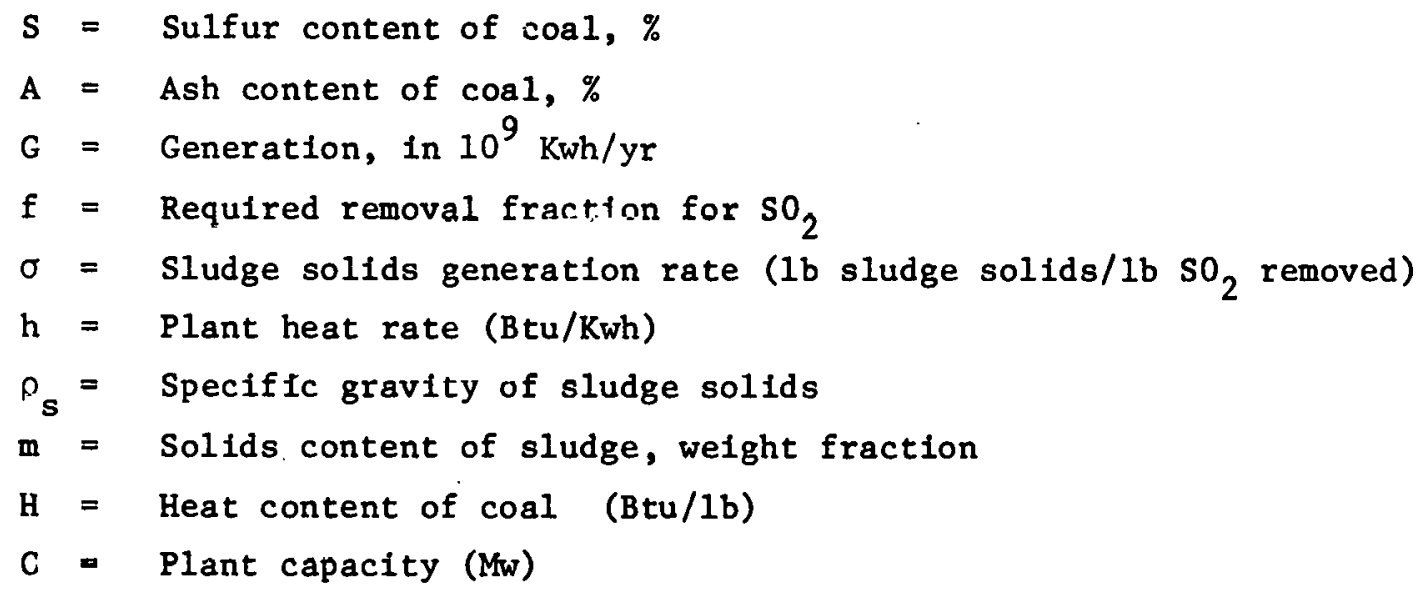

2. Electricity generation, G, from a power plant of capacity C. If the plant capacity, in $M w$, is $C$, and the plant factor is $\rho_{f}$, then

$$
\begin{gathered}
\left.G=\mathrm{C} \cdot 8760 \cdot \frac{1}{10^{9}} \cdot \frac{\rho_{\mathrm{f}}}{\mathrm{M}} \cdot \frac{10^{3}}{\mathrm{Yr}}\right]\left[\frac{\mathrm{hrs}}{\mathrm{yr}}\right] \cdot\left[\frac{10^{9} \mathrm{Kw}}{\mathrm{Kw}}\right]\left[\frac{\mathrm{Kw}}{\mathrm{Mw}}\right]
\end{gathered}
$$

3. Sulfur content in $1 \mathrm{~b} \mathrm{SO}_{2} \frac{110^{6} \mathrm{Btu}}{\left[\mathrm{S}^{7}\right]}$

$$
\begin{aligned}
& S^{\prime}=\mathrm{S} \quad \frac{1}{100} \cdot \frac{1}{\mathrm{H}} \cdot 1.9 \cdot 10^{6} \\
& {\left[\frac{1 \mathrm{~b} \mathrm{su}_{2}}{10^{6} \mathrm{Btu}}\right]=\left[\frac{1 \mathrm{~b} s}{10^{2} 1 \mathrm{~b} \text { Coal }}\right]\left[\frac{10^{2} 1 \mathrm{~b} \text { Coal }}{1 \mathrm{~b} \text { Cual }}\right] \cdot\left[\frac{1 \mathrm{~b} \text { Coal }}{\mathrm{Btu}}\right]\left[\frac{1 \mathrm{~b} \mathrm{sO}_{2}}{1 \mathrm{~b} s}\right]\left[\frac{\mathrm{Btu}}{10^{6} \mathrm{Btu}}\right]} \\
& \text { - } \frac{19000 S}{H}
\end{aligned}
$$


Note that exact stochlometry would require $1.998 \mathrm{1b} \mathrm{s0} / 1 \mathrm{~b} s$ - the difference being that some fraction of the sulfur remaing in the ash. 1.9 is the factor in general use. 1

4. Required $\mathrm{SO}_{2}$ Removal Fraction, $\mathrm{f}$

Four cases must be considered, as follows

(a) For $80 \% \mathrm{SO}_{2}$ removal, $f=.8$

(b) For $90 \% \mathrm{sO}_{2}$ removal, $\mathrm{f}=.9$

(c) For NSPS of $1.21 \mathrm{~b} \mathrm{~s} 0_{2} / 10^{6} \mathrm{Btu}$

$$
\begin{array}{ll}
\mathrm{f}=1-\frac{1: 2 \mathrm{H}}{19000 \mathrm{~S}} & \text { 1f } \mathrm{f}>0 \\
\mathrm{f}=0 . & \text { if } \mathrm{f} \leq 0
\end{array}
$$

(d) For NSPS of $0.61 \mathrm{~b} \mathrm{SO}_{2} / 10^{6} \mathrm{Btu}$

$$
\begin{array}{ll}
f=1-\frac{0.6 \mathrm{H}}{19000 \mathrm{~S}} & \text { 1f } \mathrm{f}>0 \\
\mathrm{f}=0 & \text { 1f } \mathrm{f} \leq 0
\end{array}
$$

5. Ash Production, $10^{6}$ tons/yr $\left[\mathrm{W}_{\mathrm{A}}\right]$

Defining $f_{F}=$ fraction of ash to bottom ash

$\varepsilon \quad=$ prectpitator efficiency

$\mathrm{W}_{\mathrm{A}}=\mathrm{G} \cdot 10^{9} \cdot \mathrm{h} \cdot \frac{1}{\mathrm{H}} \cdot \frac{\mathrm{A}}{100}\left[1-\mathrm{f}_{\mathrm{F}}(1-\varepsilon)\right] \cdot \frac{1}{2000} \cdot \frac{1}{10^{6}}$

$\left[\frac{10^{9} \mathrm{Kwh}}{\mathrm{Yr}}\right]\left[\frac{\mathrm{Kwh}}{10^{9} \mathrm{Kwh}}\right]\left[\frac{\mathrm{Btu}}{\mathrm{Kwh}}\right] \quad\left[\frac{1 \mathrm{~b}_{\mathrm{c}}}{\mathrm{Btu}}\right]\left[\frac{1 \mathrm{~b}_{\mathrm{Ash}}}{1 \mathrm{~b}_{\mathrm{c}}}\right] \quad\left[\frac{\mathrm{ton}}{1 \mathrm{~b}}\right] \quad\left[\frac{\mathrm{Mt}}{\operatorname{ton}}\right]$

$=\frac{G h A\left\{1-f_{F}(1-\varepsilon)\right\}}{200 \mathrm{H}}\left[\frac{\mathrm{MMt}}{\mathrm{yr}}\right]$

6. Ash Landf111. Acreage Requirements, acres/yr $\left[\mathrm{L}_{\mathrm{A}}\right]$

If $\delta_{A}$ is the disposal density of ash solids, then

Isee e.g. AP42, "Compilation of Alr Pollution Emloolon Factorg" EPA, 2nd Edition, April 1973. 


$$
\begin{aligned}
\mathrm{L}_{\mathrm{A}} & =\mathrm{W}_{\mathrm{A}} \cdot 2 \times 10^{9} \cdot \frac{1}{\delta_{\mathrm{A}}} \cdot \frac{1}{\mathrm{~d}} \cdot \frac{1}{43560} \\
& {\left[\frac{\mathrm{MMt}}{\mathrm{yr}}\right] \cdot\left[\frac{\mathrm{cu} \cdot \mathrm{ft}}{1 \mathrm{Mt}}\right]\left[\frac{1}{\mathrm{ft}}\right] \cdot\left[\frac{\text { acres }}{\mathrm{ft}^{2}}\right] } \\
& =\frac{45913 \mathrm{~W}_{\mathrm{A}}}{\delta_{\mathrm{A}}^{\mathrm{d}}}\left[\frac{\text { acres }}{\mathrm{yr}}\right]
\end{aligned}
$$

7. Sludge Solids, in MMt/yr $\quad\left[W_{s}\right]$

$$
\begin{aligned}
& \mathrm{W}_{s}=\mathrm{G} \cdot 10^{9} \cdot \mathrm{h} \cdot \frac{19000 \mathrm{~S}}{\mathrm{H}} \cdot \frac{\mathrm{l}}{10^{6}} \cdot \frac{1}{2000} \cdot \sigma \cdot \mathrm{f} \cdot \frac{1}{10^{6}} \\
& \left.\left[\frac{10^{9} \mathrm{Kwh}}{\mathrm{yr}}\right]\left[\frac{\mathrm{Kwh}}{10^{9} \mathrm{Kwh}}\right]\left[\frac{\mathrm{Btu}}{\mathrm{Kwh}}\right]\left[\frac{1 \mathrm{~b} \mathrm{SO}_{2}}{10^{6} \mathrm{Btu}}\right]\left[\frac{10^{6} \mathrm{Btu}}{\mathrm{Btu}}\right]\left[\frac{\text { tons }}{1 \mathrm{~b}}\right]\left[\frac{1 \mathrm{~b} \text { Solids }}{1 \mathrm{~b} \mathrm{SO}_{2}}\right][]^{10} \frac{\mathrm{MMt}}{\text { tons }}\right] \\
& W_{g}=\frac{.0095 G h s \sigma f}{H}\left[\frac{M M t}{y}\right]
\end{aligned}
$$

For IIme/limestone scrubber, $\sigma$ has a typical value of $2.83 .^{2}$

8. Wet weight of sludge, MMt/yr $\quad\left[W_{w}\right]$

$$
W_{w}=\frac{W_{s}}{m}=\frac{.0095 \mathrm{G} \mathrm{h} s \sigma f}{\mathrm{mH}}\left[\frac{\mathrm{MMt}}{\mathrm{yr}}\right]
$$

9. Sludge Volume, in MM cu.yds/yr $[\mathrm{V}]$

If $\rho_{S}$ is the density of sludge, in $1 \mathrm{~b} / \mathrm{cu} . \mathrm{ft}$

$$
\begin{aligned}
& \text { henre } \quad v-W_{w} \cdot 2 \times 10^{9} \cdot \frac{1}{\delta_{S}} \cdot \frac{1}{27} \cdot \frac{1}{10^{6}} \\
& {\left[\frac{M M t}{y r}\right] \quad\left[\frac{1 b}{M M t}\right] \quad\left[\frac{c u \cdot f t}{1 b}\right] \quad\left[\frac{c u \cdot y d}{c u \cdot f t}\right] \quad\left[\frac{M M c u \cdot y d}{c u \cdot y d}\right]} \\
& =\frac{74.07 \mathrm{~W}_{\mathrm{W}}}{\delta_{8}} \quad\left[\frac{\mathrm{MM} \mathrm{cu} \cdot \mathrm{yd}}{\mathrm{yr}}\right]
\end{aligned}
$$

2As based on results reported to EPA from 9 plants using either 1 ime or limestone wet scrubbers, and presented in the Development Document for Proposed Effluent Limitations Guidelines and New Source Performance Standards for the Steam Electric Generating Po1nt Source Category, \#440-1-73/029, March 1974. Th1s value is also used in the FEA Final Environmental Impact Statement for ESECA. 
10. FGD Sludge Landf111 Acreage Requirements, in acres/yr $[\mathrm{L} s]$

If $\mathrm{d}=$ depth of the pond, in $\mathrm{ft}$,

$$
\begin{aligned}
\mathrm{L}_{s} & \left.=\mathrm{V} \cdot 27 \cdot \frac{1}{\mathrm{~d}} \cdot \frac{10^{6}}{\left.\frac{\mathrm{MM} \mathrm{cu} \cdot \mathrm{yd}}{\mathrm{yr}}\right]\left[\frac{\mathrm{cu} \cdot \mathrm{ft}}{\mathrm{cu} \cdot \mathrm{yd}}\right]} \cdot \frac{1}{\mathrm{ft}}\right] \cdot \frac{1}{43560} \\
& =\frac{619.83}{\mathrm{~d}} \mathrm{~V}
\end{aligned}
$$

\section{Assumptions used in this report}

Unless otherwise noted, the following assumptions are used in this report to determine solid waste production from a new coal fired power plant of capacity C Mw:

- Plant heat rate, $\mathrm{h}=10,000 \mathrm{Btu} / \mathrm{Kwh}$

- Plant factor, $P_{f}=0.65$

- Fraction of ash to bottom ash, $f_{F}=.50$

- Precipitator efficiency, $\varepsilon=.995$

- Depth, in feet, of disposal pond, $d=30$

- Disposal density of ash solids, $\delta_{A}=80$

- Sludge solids generation rate (1b of sludge solids/lb of $\mathrm{SO}_{2}$ removed),

- Solids content of sludge, weight fraction, $m=0.5$

- Density of sludge solids, $\rho_{s}=80$

- Required $\mathrm{SO}_{2}$ removal fraction, $f=0.80$

With those assumptions and equations (1) to (5) above, we obtain:

- Ash production, $10^{6}$ tons/yr/MW[ $\left[\mathrm{W}_{\mathrm{A}}\right]$

$$
\mathrm{W}_{\mathrm{A}}=0.284 \frac{\mathrm{A}}{\mathrm{H}}
$$

- Ash landfill acreage requirement, acres/yr/MW $\left[\mathrm{L}_{\mathrm{A}}\right]$ :

$$
\mathrm{L}_{\mathrm{A}}=5.433 \frac{\mathrm{A}}{\mathrm{H}}
$$


- Wet weight of FGD sludge, $10^{6}$ tons $\mathrm{yr} / \mathrm{Mw} \quad\left[\mathrm{W}_{\mathrm{WT}}^{\cdot}\right]$ :

$$
W_{W}=2.449 \frac{\mathrm{S}}{\mathrm{H}}
$$

- FGD Sludge landfill acreage requirement, in acres/yr, $\left[\mathrm{L}_{\mathrm{L}} \mathrm{S}\right]$

$$
\mathrm{L}_{\mathrm{S}}=46.848 \frac{\mathrm{S}}{\mathrm{H}}
$$

Thus a 1,000 Mw power plant using coal of heat content $11,000 \mathrm{Btu} / 1 \mathrm{~b}$ with a $12 \%$ ash content and $3 \%$ sulfur content will produce about 310,000 tons of dry ash and 570,000 tons of wet FGD sludge per year, requiring disposal areas of 6 and 13 acres respectively. 
Append1x B:

Supporting Tables For Industrial Analysis 
TABLE 13

ASSUMED USE OZ FGD SYSTEMS IN 1985

(As a percent of all coal used In the Indicated category)

FRA/EPA

Region

W1th Current A1r Pollution Standards (a)

$\begin{aligned} & \text { Exiating } \\ & \text { Sources }\end{aligned}$
$\underline{\text { Large }}$

1 New England

$2 \mathrm{NY} / \mathrm{NJ}$

3 Mid-Atlantic

4 South-Atlantic

5 Mid-West

6 South West

7 Central

8 North Central

9 West

$\begin{array}{lll}0 & 75 & 0\end{array}$

$90 \quad 90 \quad 90$

15

$70 \quad 15$

0

60

0

7530

30

10

0

0

300

15

$15 \quad 15$

so

$50 \quad 50$

10 North West

15

$50 \quad 15$

W1th BACT A1r Pollution Standardo $(b)$

Existing New
Sources $\quad \begin{gathered}\text { New } \\ \text { Large }\end{gathered}$

$\begin{array}{rll}0 & 100 & 75 \\ 90 & 100 & 90 \\ 15 & 100 & 50 \\ 0 & 100 & 15 \\ 30 & 100 & 35 \\ 0 & 100 & 10 \\ 0 & 100 & 30 \\ 15 & 100 & 15 \\ 50 & 100 & 50 \\ 15 & 100 & 50\end{array}$

(a) Corresponding $\mathrm{SO}_{2}$ removal efficlency is assumed to be as follows: for new large sources ( $>25 \mathrm{Mw}$ ), $80 \%$ in all regions; for new small sources and and existing sources, $68 \%$ in Region 2, $59 \%$ in Region 3, $72 \%$ in Region 5 , and $80 \%$ in Regions $8,9,10$. Th1s meets NSPS levels for new large sources, SIP levels for existing and new small.

(b) Corresponding $\mathrm{SO}_{2}$ removal efficiency is assumed to be $80 \%$ for all new sources

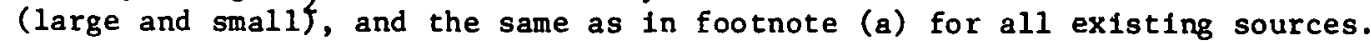
This 1s assumed to yleld an $80 \%$ reduction for new large sources and an average emission rate of $1.51 \mathrm{~b} \mathrm{SO}{ }_{2} / 10^{6}$ Btu for new small sources.

Source: Executive office of the President. 
TABLE 14

DISTRIBUTION OF INDUSTRIAL COAL USE: 1985 BASE CASE

$$
\left(10^{12} \mathrm{Btu}\right)
$$

\begin{tabular}{|c|c|c|c|c|c|c|c|c|c|}
\hline \multirow[b]{2}{*}{$\begin{array}{l}\text { FEA/EPA } \\
\text { Reglon } \\
\end{array}$} & \multirow{2}{*}{$\begin{array}{l}\text { Total } \\
\text { Coal } \\
\text { Use }(a) \\
\end{array}$} & \multicolumn{2}{|c|}{$\begin{array}{l}\text { Exloting } \\
\text { Sources }\end{array}$} & \multicolumn{3}{|c|}{ New Large Source $\left(>25 w_{w}^{(c)}\right)$} & \multicolumn{2}{|c|}{ New Small } & Sources (<25Mw) \\
\hline & & Total & $\frac{8}{F G D(d)}$ & Total & $\begin{array}{l}\text { PGD Yol) } \\
\text { NSPS }\end{array}$ & $\begin{array}{l}\text { FGD Y/ } \\
\text { BACT }\end{array}$ & Total & $\begin{array}{l}\text { FGD w/ } \\
\operatorname{SIP}(d) \\
\end{array}$ & $\begin{array}{l}\text { FGD w// } \\
\text { BACTI }\end{array}$ \\
\hline 1. New England & 4.8 & 3.29 & 0 & 0.75 & 0.56 & 0.75 & 0.75 & 0 & 0.56 \\
\hline $2 \mathrm{NY} / \mathrm{NJ}$ & 86.5 & 44.14 & 39.73 & 21.17 & 19.05 & 21.17 & 21.17 & 19.05 & 19.05 \\
\hline 3 Mdd-Atlant1C & 382.8 & 231.02 & 34.65 & 75.87 & 53.11 & 75.87 & 75.87 & 11.38 & 37.94 \\
\hline 4 South Atlentic & 368.4 & 147.76 & 0 & 110.32 & 66.19 & 110.32 & 110.32 & 0 & 16.55 \\
\hline 5 M1d-West & 1044.1 & 406.65 & 122.00 & 318.72 & 239.04 & 318.72 & 318.72 & 95.62 & 111.55 \\
\hline 6 South West & 99.8 & 26.54 & 0 & 36.62 & 3.66 & 36.62 & 36.62 & 0 & 3.66 \\
\hline 7 Central & 83.3 & 52.80 & 0 & 15.26 & 4.58 & 15.26 & 15.26 & 0 & 4.58 \\
\hline 8 North Central & 98.8 & 34.63 & 5.19 & 32.09 & 4.81 & 32.09 & 32.09 & 4.81 & 4.81 \\
\hline 9 West & 36.2 & 6.10 & 3.05 & 15.05 & .7 .53 & 15.05 & 15.05 & 7.53 & 7.53 \\
\hline 10 North West & 68.6 & 17.98 & 2.70 & 25.30 & 12.65 & 25.30 & 25.30 & 3.80 & 12.65 \\
\hline U.S. Total & 2270.6 & 968.35 & 207.32 & 651.14 & 411.18 & 651.14 & 651.14 & 142.19 & 218.88 \\
\hline
\end{tabular}

(a) Based on PIES model coal projections.

(b) Assumes existing (1975) sources retire at $3 \%$ per year during 1975-85, and that all sources have same load factor.

(c) Assumes large and small new sources each consume 50\% of coal used by all new sources (based on 1974 MFBI survey).

(d) Allocated according to Table 13, under current regulation.

(e) Allocated according to Table 13, assuming BACT. 
TABLE 15

DISTRIBUTION OR 1985 RBGIONAL COAL USB IMCREASES DUB TO NEP

$$
\text { (10. }{ }^{12} \text { Btu) }
$$

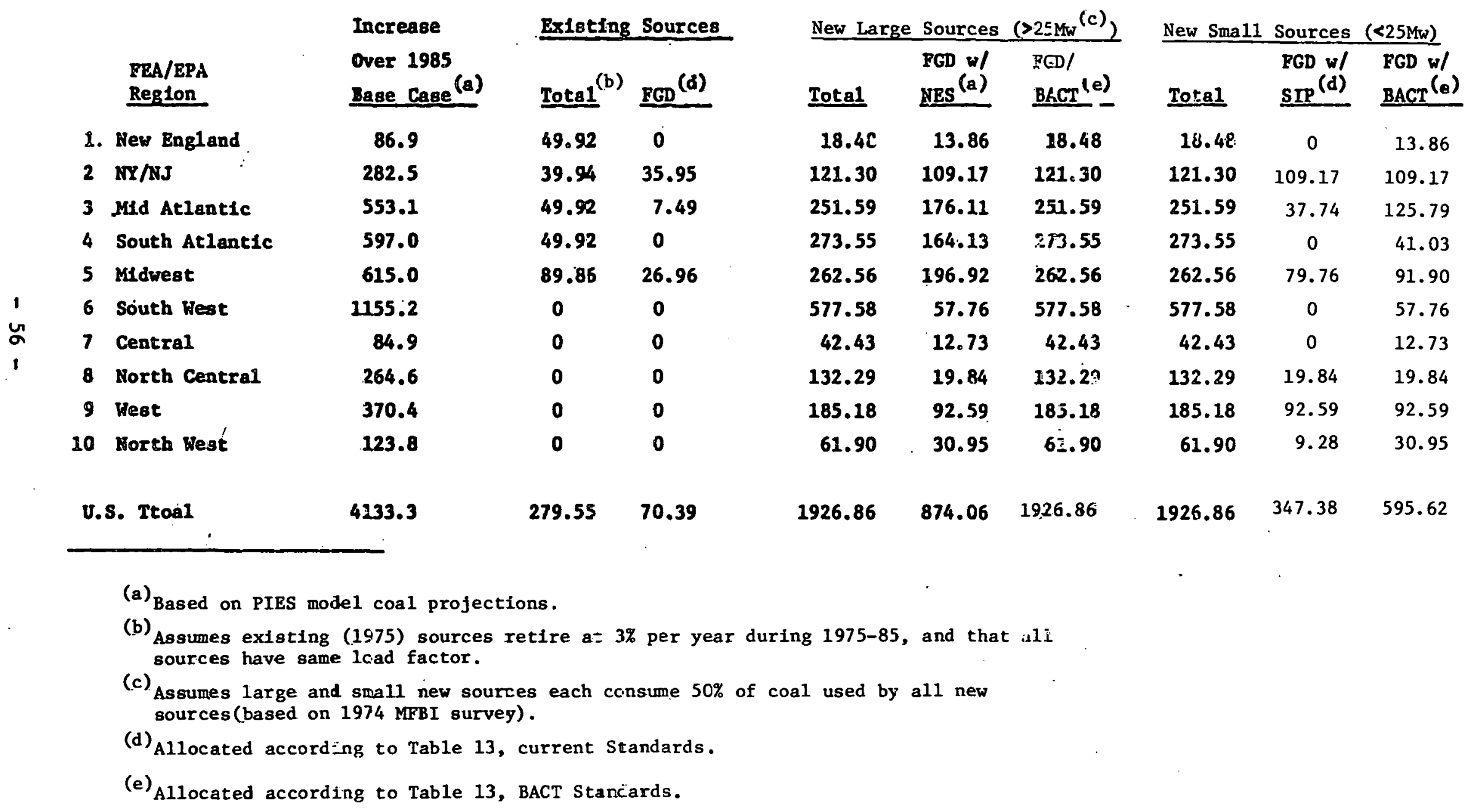


TABLE 16

ESTIMATED FGD USE ASSUMING BACT

$10^{12}$ Btu of coal scrubbed

(Approx. no. of combustors ${ }^{a}$ )

\begin{tabular}{|c|c|c|c|}
\hline & & & \\
\hline $\begin{array}{l}\text { Existing } \\
\text { Sources }\end{array}$ & $\begin{array}{l}\text { New } \\
\text { Large }\end{array}$ & $\begin{array}{l}\text { New } \\
\text { Sma11 }\end{array}$ & Total \\
\hline
\end{tabular}

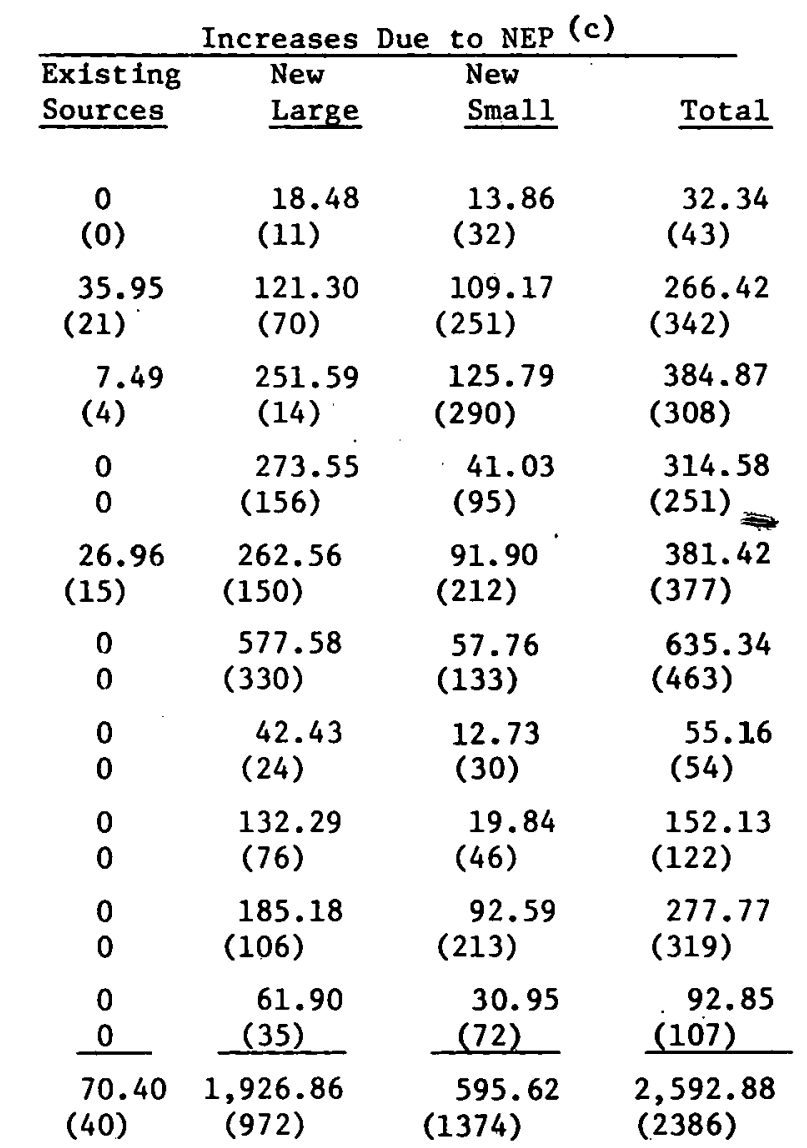

approx. No. of combusters indicated in parentheses: assumes all units at $50 \%$ annual average capacity factor, with average plant sizes of $40 \mathrm{Mw}$ for existing and new large factlities, 10 Mw for new small units.

$\mathrm{b}_{\text {from }}$ Table 14 .

crom Table 15 . 
TABLE 17

ESTIMATED PRODUCTION OF DRY ASH FOR ALL AIR POLLUTION CONTROL SCENARIOS

(million tons per year) $)^{(a)}$

\begin{tabular}{|c|c|c|c|c|c|c|c|c|c|c|}
\hline & \multirow[b]{2}{*}{$\begin{array}{l}\text { FEA/EPA } \\
\text { Reg1on } \\
\end{array}$} & \multirow{2}{*}{$\begin{array}{r}\text { Average } \\
\text { Coal } \\
\text { Ash }(b) \\
\left(1 \mathrm{bs} / 10^{6}\right. \\
\text { Btu) } \\
\end{array}$} & \multicolumn{4}{|c|}{1985 Ease Case } & \multicolumn{4}{|c|}{ Ircrease Due to NEP } \\
\hline & & & $\begin{array}{l}\text { Rxisting } \\
\text { Sources }\end{array}$ & $\begin{array}{l}\text { New } \\
\text { Large }\end{array}$ & $\begin{array}{l}\text { New } \\
\text { Sma11 }\end{array}$ & Tota1 & $\begin{array}{l}\text { Exist1ng } \\
\text { Sources }\end{array}$ & $\begin{array}{l}\text { New- } \\
\text { Large }\end{array}$ & $\begin{array}{l}\text { New } \\
\text { Sma11 }\end{array}$ & Total \\
\hline 1 & New England & 7.1 & 0.012 & 0.003 & 0.003 & 0.017 & 0.176 & 0.065 & 0.065 & 0.306 \\
\hline 2 & $\mathrm{NY}, \mathrm{NJ}$ & 10.6 & 0.233 & 0.112 & 0.112 & 0.456 & 0.211 & 0.640 & 0.640 & 1.491 \\
\hline 3 & Med-Atlantic & 13.4 & 1.555 & 0.511 & 0.511 & 2.567 & 0.336 & 1.693 & 1.693 & 3.722 \\
\hline 4 & South Atlantic & 12.5 & 0.928 & 0.693 & 0.693 & 2.313 & 0.313 & 1.717 & 1.717 & .3 .747 \\
\hline 5 & M1d-West & 11.7 & 2.390 & 1.873 & 1.873 & 6.135 & 0.538 & 1.543 & 1.543 & 3.624 \\
\hline 6 & South West & 21.7 & 0.289 & 0.399 & 0.399 & 1.088 & 0 & 6.295 & 6.295 & 12.590 \\
\hline 7 & Ceritral & 11.6 & 0.308 & 0.089 & 0.089 & 0.485 & 0 & 0.247 & 0.247 & 0.494 \\
\hline 8 & North Central & 11.5 & 0.200 & 0.185 & 0.185 & 0.571 & 0 & 0.764 & 0.764 & 1.528 \\
\hline 9 & West & 9.3 & 0.028 & 0.070 & 0.070 & 0.169 & 0 & 0.865 & 0.865 & 1.730 \\
\hline 0 & North West & 18.5 & 0.168 & $\underline{0.235}$ & 0.235 & 0.637 & 0 & 0.575 & 0.575 & 1.150 \\
\hline & U.S. Total & & 6.111 & 4.170 & +.170 & 14.451 & 1.574 & 14.404 & 14.404 & 30.382 \\
\hline
\end{tabular}

Total

a) Actur most likely to be the case where an FGD system is also required.

(b) Assuming use of locally ayailable coal. 
TABLE 18

ESTIMATED MAXIMUM PRODUCTION OF FGD DISSOLVED SOLIDS

ASSUMING BACT ${ }^{\mathbf{a}}$ (million tons/yr)

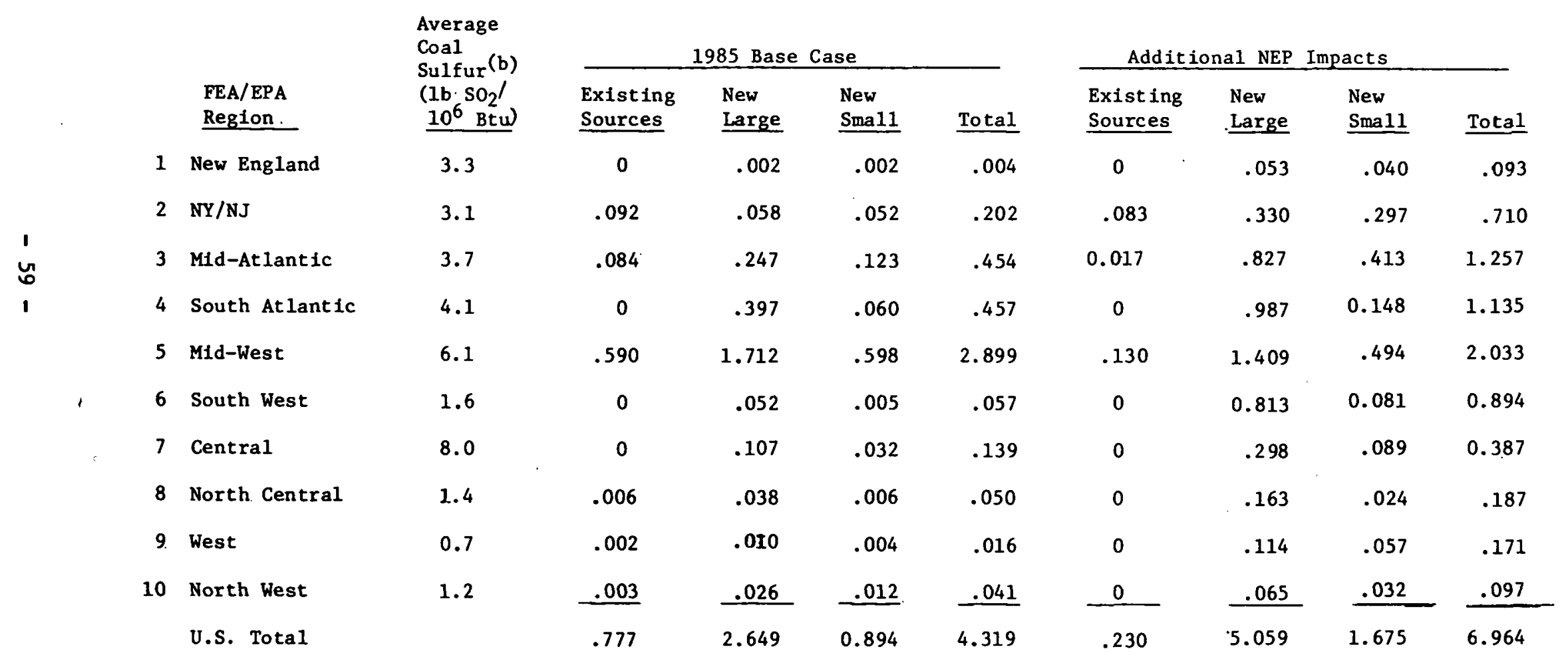

assumes 4.441b dissolved solid/1b Sulfur removed, characteristic of Sodium. Sulfate from an alkaline liquid scrubbing system. 
TABLE 19

ESTIMATED MAXIMUM PRODUCTION OF WET SLUDGE ASSUMTNG BACT ${ }^{2}$

(million tons/year)

\begin{tabular}{|c|c|c|c|c|c|c|c|c|c|c|c|}
\hline & & \multirow[b]{2}{*}{$\begin{array}{l}\text { FEA/EPA } \\
\text { Region }\end{array}$} & \multirow{2}{*}{$\begin{array}{l}\text { Average } \\
\text { Ccal } \\
\text { Sulfur } \\
\left(1 \mathrm{~b} \mathrm{SD}_{2} /\right. \\
\left.10^{6} \mathrm{Btu}\right)\end{array}$} & \multicolumn{3}{|c|}{1785 Base Case } & & \multicolumn{3}{|c|}{ Additional NEP Impacts } & \multirow[b]{2}{*}{ Total } \\
\hline & & & & $\begin{array}{l}\text { Existing } \\
\text { Sources } \\
\end{array}$ & $\begin{array}{l}\text { New } \\
\text { Large }\end{array}$ & $\begin{array}{l}\text { New } \\
\text { Smal1 } \\
\end{array}$ & Total & $\begin{array}{l}\text { Exist1ng } \\
\text { Sources } \\
\end{array}$ & $\begin{array}{l}\text { New } \\
\text { Large } \\
\end{array}$ & $\begin{array}{l}\text { New } \\
\text { Smal1 } \\
\end{array}$ & \\
\hline & 1 & New England & 5.3 & 0 & .005 & .005 & .010 & 0 & .144. & .109 & .253 \\
\hline & 2 & $\mathrm{NY} / \mathrm{NJ}$ & 3.1 & .247 & .156 & .139 & .542 & .224 & .887 & .797 & 1.908 \\
\hline & 3 & Mid-Atlancic & 3.7 & .224 & .663 & .330 & 1.217 & .047 & 2.197 & 1.098 & 3.342 \\
\hline 1 & 4 & South Atlantic & 4.1 & 0 & 1.066 & .160 & 1.226 & 0 & 2.648 & 0.397 & 3.045 \\
\hline g & 5 & Mid-West & $\epsilon .1$ & .1 .581 & 4.587 & 1.604 & 7.772 & .349 & 3.781 & 1.322 & 5.452 \\
\hline I & 6 & South West & 1.6 & 0 & .1239 & .014 & .153 & 0 & 2.180 & 0.219 & 2.399 \\
\hline & 7 & Central & 8.0 & 0 & .287 & .087 & .374 & 0 & 0.800 & 0.241 & 1.041 \\
\hline & 8 & North Central & 1.4 & .017 &. \pm 06 & .016 & .139 & 0 & .437 & .066 & .503 \\
\hline$\sum_{\substack{4 \\
0}}^{4}$ & 9 & West & 0.7 & .005 & .026 & .012 & .043 & 0 & .307 & .153 & .460 \\
\hline 雀 & 10 & North West & 1.2 & .058 &.$C 71$ & .033 & .111 & $\underline{0}$ & .174 & 0.088 & 0.262 \\
\hline 㳯 & & S. Total & • & 2.081 & 7.106 & 2.400 & 11.587 & 0.620 & 13.555 & 4.490 & 18.665 \\
\hline
\end{tabular}

Assumes 11.80 Ib Wet Sludge/lo of sulfur removed, characteristic of Calcium Sulfite/Sulfate Mixtures from dual alkali systems dewatered to $50 \%$ solids.

bssuming uze of locally avallable coal. 